\title{
Guerrilla warfare and resource extraction
}

Post-independence ethnic minorities inhabiting the Southeast Asian borderlands were willingly or unwillingly pulled into the macro politics of territoriality and state formation. The rugged and hilly borderlands delimiting the new nation-states became spaces of confrontation between divergent political ideologies. In the majority of the Southeast Asian borderlands, this implied catastrophic disruption in the lives of borderlanders that came to affect their relationship to their nationstate.

The politically muddled and wrenching processes of nation-building that took place along Indonesia's longest land border in the 1960s and 1970s provide a vivid example of the ambivalent relationship between ethnic minorities, like the Iban, and the central Indonesian state. This is particularly so with respect to the deep anxiety concerning ethnic minorities' susceptability to Communist infiltration. This government anxiety created an often strained and violent relationship. The idea that 'backward' ethnic minorities were especially prone to Communist influence and subsequent engagement in subversive acts of insurgency against pro-Western governments was a general fear among Western powers and allied states throughout Southeast Asia (CIA Intelligence Report 1970, 1973). Here borderlands often became key battlefields in preventing the spread of communism and 'saving' Southeast Asia from falling into the hands of communist regimes.

One aim of this chapter is to unravel the little-known history of how the Iban segment of the Indonesian border population became entangled in the highly militarized international disputes with neighbouring Malaysia in the early 1960s and in subsequent military cooperative 'anti-communist' 'counter-insurgency' efforts by the two states in the late 1960s and 1970s. What follows brings together facets of national belong- 
ing and citizenship within the borderland context largely based on local narratives.

Throughout the highly authoritarian New Order regime of President Soeharto (1965-1998), the fight against the perceived Communist threat impinging on its national border, on the island of Borneo, was popularly portrayed as a grand success that induced great national pride. State rhetoric stressed how stern military actions effectively subdued and drove out the Communist insurgents from their hideouts in the hilly, heavily forested borderlands. These military deeds were supposedly executed with the support of the 'patriotic' borderland populations. While such state rhetoric played an important role in maintaining the idea of the Unitary State of the Republic of Indonesia (NKRI), local narratives tell a rather different and less flattering story of state violence and broken promises of development assistance.

Another purpose of the chapter is to show how today's border elite power base and its networks of influence were, in many ways, established in the early 1960s, when the borderland was plunged into armed conflict with the newly established federation of Malaysia. Much has been written about this period of militarization as it unfolded in the lower and middle part of the West Kalimantan province and how it affected ethnic Chinese communities, but there is a general lack of research on how this violent period affected the communities further inland along the border in districts like Kapuas Hulu.

\section{KONFRONTASI: STATE MAKING ON THE BORDER}

The early period of Indonesian state formation and nationalism went largely unnoticed in the remote borderlands until the early 1960s, when the Malaysian Federation, protected by its former colonial masters, the British, was is the process of being established (Jones 2002; Mackie 1974; Subritzky 2000). The Malay Peninsula became independent in 1957 as the Federation of Malaya. Subsequently, in 1961, the Malayan Prime Minister suggested an enlargement of the federation to include Singapore, Sarawak, British North Borneo, (the current Sabah) and Brunei. ${ }^{1}$

\footnotetext{
1 Singapore and Brunei decided not to become part of the federation and instead created their own independent states.
} 
Political turmoil and the spread of communism in the region greatly induced the former British colonizers to maintain their authority in the region, by giving strategic support to a Malay pro-Western federation. At that time, the new Indonesian republic, under the leadership of President Soekarno, reacted strongly towards this suggestion of creating a Malaysian nation-state, which from the Indonesian side was seen as no less than a neo-imperialistic threat to its interests in the region. Soekarno had a vision of a united Borneo under the administration of Indonesia and believed that the formation of a Malaysian federation was a British attempt to shore up its power base in the region, which Soekarno termed the Nekolim (neo-colonialists-imperialist) threat (Easter 2005).

In an attempt to undermine the hatchling Malay Federation before it could develop, Soekarno's left-wing government gave its support to a leftist militant group, the North Kalimantan National Army (TNKU) by providing training and arms. ${ }^{2}$ The TNKU was formed from the remnants of a 1962-failed rebellion against the British-protected Sultanate of Brunei and the British Crown Colonies of Sarawak and North Borneo. One should keep in mind that there is no one standard view of the motivations behind Soekarno's confrontational policy. His military served a range of ideological, strategic and political purposes. Several scholars for example explore Soekarno's ambition to see that Indonesia take control of the region and assume leadership of an alliance including Malaya, the Philippines and Indonesia to be known as 'Maphilindo', as one such motivation. A strong British presence in the region was seen as a major impediment to the creation of Maphilindo (Gregorian 1991). Others mention that the domestic power struggle going on at the time led to Soekarno's allegations of neocolonialism as a smokescreen for engaging the military in the conflict, thereby keeping it occupied (Sodhy 1988).

Under the heading 'Mission: Liberation - Armed Indonesians on the march', The Borneo Bulletin, a Brunei weekly newspaper, published a front-page story 26 May 1962. The story described how Sarawak tribesmen had seen about 1000 men trekking through the jungle towards the Indonesian border. According to the newspaper, these men, a mix of Malay, Iban and other 'races', were on the way to Kalimantan to be trained for an Indonesian-led Borneo 'Liberation Army', which would

$2 \quad$ For a detailed account of the TNKU and the Brunei rebellion, see Mackie 1974. 
return to 'liberate' the three states of Brunei, Sarawak and British North Borneo (Sabah) from the Sultan and the British colonizers (Brackman 1966:140; Majid 2007:76-7). A few months later, on 8 December 1962, an armed uprising broke out in the British-protected Sultanate of Brunei and in several nearby towns of the British Crown Colonies of Sarawak and North Borneo (Mackie 1974:117). ${ }^{3}$ The armed revolt was a result of a long conflict between the Brunei left-wing party named Ra'ayat (People's Party) and the government (the Sultanate and the British), and it later came to be known as the Brunei Rebellion. ${ }^{4}$ The Ra'ayat opposed the British idea of creating a Malaysian State and preferred that the federation cede Sarawak and its eastern neighbour Sabah. The Ra'ayat Party drew its inspiration from Soekarno's Indonesia, and they wanted to unite all Borneo territories and form their own independent state - the North Kalimantan Unitary State (Negara Kesatuan Kalimantan Utara, or NKKU) (Stockwell 2004). At the onset of the rebellion, the British military command in Singapore quickly dispatched a few thousand troops to fight the rebels in Brunei and the neighbouring Crown Colonies. The troops were a mixture of British Commandos and Gurkhas (Harold and Sheil-Small 1971). The uprising was led and organized by a group of hard core insurgents who had military training from West Kalimantan (Fujio 2005). Despite its strong local support, the rebellion was badly planned, and the British soldiers defeated the rebels in two weeks. However, one group of rebels escaped and retreated to the border area between Sarawak and Kalimantan, where they initiated guerrilla warfare against Malaysian soldiers and mixed brigades of British, Australian and New Zealand Commonwealth troops (Dennis and Grey 1996; Pugsley 2003). In 1964 as many as 30,000 British soldiers were reportedly employed in this undeclared war, one of the largest British military operation since World War II (Tuck 2004:93). ${ }^{5}$

Under the pretext of supporting the TNKU's armed struggle against

In 1946, Sarawak became a British crown colony.

4 The leader of the rebellion was a Brunei politician, A.M. Azahari, who was originally educated in Indonesia where he also was active in the Indonesia independence struggle against the Dutch (Stockwell 2004:793).

5 In the years leading up to the British military involvement on the Indonesian border the British government was reluctant to apply direct military force. They thought that military involvement should be a last resort in order to maintain diplomatic and commercial relations with Indonesia. However, as the Indonesians were not 'up for compromise', the only solution envisioned was to bring Indonesia to its 'knees by a prolonged process of attrition'. See 'Cabinet: Policy towards Indonesia', 6-1-1964, Cabinet papers CP (64) 5, British National Archives, Kew, Richmond, Surrey. 
the creation of a Malaysian federation, President Soekarno's left-wing government dispatched Indonesian volunteers (dwikora sukarelawan) to help. The term dwikora (Dwi Komando Rakyat/People's Twin Commands) became the slogan for this anti-Malaysia campaign, encouraging the engagement of the 'people' in the fight. The volunteers were recruited among local Indonesians supportive of the cause, especially among those with sympathy to the Indonesian Communist Party (PKI). Many of these were ethnic Chinese and Javanese, although Iban and other Dayaks from both sides of the border were also recruited (Porritt 2004:89). ${ }^{6}$ A man from Lanjak tells how he was recruited to the TNKU in 1963:

In 1960, I went abroad (merantau) to Sarawak, tapping rubber. Then a few years later the dispute between Indonesia and Malaysia broke out and because I am Indonesian I was detained in Semanggang for one month and repatriated across the border together with 130 other Indonesians. Across the border, we were quickly approached by the RPKAD (Resimen Para Komando Angkatan Darat, Army Para-Commando Regiment), ${ }^{7}$ who asked if we wanted to be volunteers (sukarelawan) of the TNKU. They said now you must register. I kept quiet but those of us who were young and fresh were chosen anyway... for three months we were trained by the RPKAD and a lieutenant from Battalion 642/Tanjungpura in handling weapons. Afterwards we marched to Hulu Kantuk with soldiers from Battalion 305 Siliwangi [Sundanese from West Java] from where we went into the jungle and attacked targets on the Malaysian side like at Batu Lintang [Sarawak]. ${ }^{8}$

Another border inhabitant 'persuaded' by the RPKAD to join the TNKU as a volunteer recollected:

I told them that I was illiterate (buta). They [the RPKAD] said 'we don't care whether you are illiterate as long as you can be trained to shoot a weapon and hide from the enemy (berlatih nembak berlatih menghilang). This doesn't need advanced education. The most important thing is that you

6 On the Malaysian side, these volunteers went under the less flattering name of Indonesian Border Terrorists or IBTs (Harold and Sheil-Small 1971:60).

7 A Special Forces unit locally known as the Red Berets (Berat Merah) that later evolved into the notorious Kopassus elite force.

8 Personal interview, ex-TNKU, Lanjak, 23-7-2007. 
can shoot.' After being trained in Hulu Kantuk [Empanang subdistrict] together with Malaysian volunteers [Sarawak and Kalimantan Chinese] we went to the border. We were 45 persons, 25 were given weapons, and the other 20 just had grenades. Our first battle was at the Setikung River; here we were attacked by Ghurkhas and many of us died, as we didn't know how to engage in combat (belum tahu perang). ${ }^{9}$

In reality, the main actors on the Indonesian side of the border in this undeclared war were Indonesian volunteers, members of the TNKU and Indonesian army troops. Two companies from the RPKAD Battalion 2 were deployed to West Kalimantan in 1963, one in Nanga Badau and one in Senaning. They were employed to stage raids into Sarawak together with the TNKU. However, the raids could not be staged as a regular Indonesian military campaign and were therefore disguised behind the TNKU banner (see Conboy 2003:96). Besides the RPKAD brigades, units from the Marine Commandos (Korps Komando Operasi, KKO) Air Force Paratroops/Fast Mobile Force (Pasukan Gerah Tjepat, PGT) and the paramilitary Police Mobile Brigade (Brigade Mobil, BRIMOB) from the Indonesian National Police also took an active part in the fighting (Pugsley 2003).

Later in 1963, the Indonesian army units together with these volunteers and rebels began making incursions across the West KalimantanSarawak border, as part of Soekarno's 'Crush Malaysia' (Ganjang Malaysia) campaign. The first incident is recorded in a Malaysian Government White Paper:

12 April 1963. The first series of armed raids in Sarawak took place when a party of some 75 armed men in uniform attacked a police station at Tebedu in Sarawak three miles from the Indonesian border. They killed a corporal and wounded two soldiers. The attackers came from and withdrew to Kalimantan (Indonesian Borneo). They spoke an Indonesian form of Malay Language. A belt left behind by one of them had Indonesian army markings and two envelopes dropped by them were addressed to persons in Pontianak in Indonesian Borneo. Indonesians had previously been inquiring into the strength of the security forces in Tebedu (KPM 1965:1). 
The incursions developed into what is known as the IndonesianMalaysian Confrontation (Konfrontasi) (Brackman 1966; Mackie 1974). Despite initial Indonesian efforts to prevent the new federation, in September 1963 Malaya merged with the Borneo territories and became an independent nation-state, although at this stage it was not formally recognized by Indonesia. Another motive for the Indonesian government's heavy militarization of Kalimantan and stationing of thousands of troops both during the latter part of Konfrontasi and the subsequent Communist uprooting was to subdue regional separatist aspirations. In the late period of Dutch colonialism and just after Indonesian independence, ideas about a pan-Dayak identity were emerging in Kalimantan. ${ }^{10}$ For example, in 1945 Iban leaders from both sides of the border met to discuss ideas of separatism and their possible role in an independent Pan-Dayak state (Wadley 1998:82). Moreover, in the 1950s the bupati of Kapuas Hulu (1951-1955) was a Dayak called Y.C Oevang Oeray who in 1960 was elected governor of the province. Oevang was one of the main figures in the pan-Dayak movement at the time. He was later removed from his post as governor and replaced by the Military Colonel Soemadi (1967-1972). Until 2008, the province was ruled by a succession of governors with military backgrounds. Jamie S. Davidson gives a detailed discussion of early Dayak elite consolidation (2003a and 2003b).

\section{A TIME OF DISRUPTION: NATIONALIST ASPIRATION AND STATE VIOLENCE}

The primary Indonesian tactic during the Confrontation was to carry out small raids into Sarawak, attacking longhouses and terrorizing Iban and other Dayak communities in an attempt to provoke a native rebellion against the new Malaysian Federation. ${ }^{11}$ The tactic largely failed because of the nearly complete lack of genuine support among most of the border population (Mackie 1974:212-3; McKeown 1983:103-5).

1o See Davidson 2003b; Peluso and Harwell 2001; Thung et al. 2004.

${ }_{11}$ For a discussion of the effects of the Konfrontasi period on communities elsewhere along the border, see Ishikawa 2010. 
6 June 1963. A group of eight Indonesian terrorists raided a village shop and a longhouse in Ensawang near Lubok Antu, the second division of Sarawak. One Iban was killed and one Security forces sergeant was wounded in this incident. The terrorists fled across the border into Indonesian territory (KPM 1965:1).

17 June 1963. A party of 30 border raiders crossed into Sarawak and surrounded a longhouse at Wong Panjoi (near Lubok Antu) but dispersed when a Defence aircraft flew over the area. From subsequent investigations, three of the raiders were recognized as having come from Badau in West Kalimantan, which is a known base for border raiders (KPM 1965:2).

Iban communities on both sides of the border were drawn into the conflict. On the Sarawak side, well-trained Malaysian soldiers assisted by British soldiers, Gurkhas and Australian troops patrolled the border using Iban and other border-dwelling Dayaks as scouts. The Iban were greatly favoured by British army patrols and often employed as trackers known as the 'Border Scouts' (a Dayak vigilante corps). Their reputation as former headhunters and fierce fighters made them valuable allies. As mentioned earlier, the Brookes had often employed Iban for the same purpose. Iban trackers were also brought over from Sarawak to the Malaysian peninsula to help track down Communists during the anticommunist Emergency campaigns in the 1940s. ${ }^{12}$ Sarawak Iban were not the only trackers; a large group of Kalimantan Iban from the Lanjak area also joined the fighting. After the end of the Emergency campaign on the Malay Peninsula, most of these men remained in what later became the new Malaysian Federation but retained their cross-border connections.

During the early 1960s, the Malay and Commonwealth troops, with the help of their Border Scouts, carried out numerous 'hot pursuit' operations code-named 'CLARET' across the border. ${ }^{13}$ Unofficially, they were permitted by high command to venture 2000 yards into Kalimantan in order to counter the TNKU and Indonesian Army cross-

12 See Dennis and Grey 1996:259; McMichael 1987:107; Pringle 1970:213.

13 The CLARET operations were kept secret by the Commonwealth forces even after the end of Confrontation. Afraid that it would strain its relations with Indonesia, Australia, for example, first recognized its involvement in these secret incursions on Indonesian territory as late as 1996 (Forbes 2005). 
border incursions, as long as the operations left no traces and were kept off the record. The Commonwealth countries did not want to be accused of violating Indonesian territory (Pugsley 2003). A similar strategy of recruiting local scouts was applied by the Indonesian military across the border in Kalimantan (Dickens 1991; Pirous 2002). Despite the fact that most Kalimantan Iban had no particular interest in the conflict, a group of Iban from the Lanjak area were 'recruited' (by force) as scouts. These unwilling scouts did their uttermost to prevent clashes between the different border patrols, Indonesian and Malaysian.

Former Iban scouts in Lanjak recount how they purposely led the Indonesian military patrols in circles around the Malaysian patrols in order to prevent clashes. In doing so, they avoided being forced to fight Iban kin employed as scouts by the 'enemy'. One very common strategy employed by Iban trackers was to use different kinds of signals to warn the oncoming Iban trackers employed by the enemy. For example, they imitated animal cries or simply wore their caps backward as a signal that regular soldiers were following close behind. The ability of the Iban to cross the border and easily blend with ethnic kin, who were also recruited by the fighting parties, was highly valued. The commanding officer of the Commonwealth forces stationed across the border in Lubok Antu recounts how he employed Kalimantan Iban 'agents' to provide intelligence on the exact location of the Indonesian Army bases in the Badau area. In many instances, the opposing troops were stationed only a few kilometres apart. Malaysian and Commonwealth troops erected army camps in Batu Lintang, Lubok Antu and Jambu across the border in Sarawak just opposite the Indonesian camps (Gurr 1995:106-7).

The Iban (and other Dayaks), trapped between the two sides and feeling no special commitment to fight, tried to protect themselves by betting on both sides in the conflict. ${ }^{14}$ During interviews, senior Iban relate how they attempted to appear neutral in the conflict, despite their strong kinship bonds with Iban communities in Sarawak. This bond posed a dilemma as several Iban tribal leaders from the Sarawak border region vocally expressed their anti-communism. For example, in 1963 two ethnic Iban leaders were appointed to strategic positions in Sarawak

${ }^{14}$ See Mackie 1974:213; McKeown 1984:105. 
politics as chief minister of Sarawak, Stephen Kalong Ningkam, ${ }^{15}$ and federal minister of Sarawak affairs, Tun Jugah Anak Barieng. Both these men were strong anti-communists who actively resisted Soekarno's Konfrontasi. Tun Jugah in his role as the principal chief of the Iban in Sarawak was highly respected in Kalimantan where he had close kinship relations. For the Kalimantan Iban, however, it was a wise strategy to avoid openly acknowledging admiration for one's Sarawak kin.

Senior inhabitants of Rumah Manah describe the years of Confrontation as a period of restrictions. The tense situation along the border made contact with relatives across the border difficult and dangerous. For many generations, crossing the border to visit family and to work or trade had been largely unhindered; now suddenly the border was patrolled by military on both sides. Consequently the border was officially 'closed' for several years. Nevertheless, with help from relatives across the border, several inhabitants from Rumah Manah continued their cross-border business throughout the Confrontation, although at considerable risk of being caught in the line of fire. Furthermore, several families took the radical decision to permanently immigrate (pindah) and join their Sarawak kin. This was largely done without permission from the Indonesian government. Almost all Iban longhouses I visited during my fieldwork had families who emigrated to Sarawak during the Confrontation. The Iban who moved across the border did not see themselves as running away, but as returning to an area from which their family had migrated a few decades ago. The Iban used the word 'pulai' to describe this movement, pulai being the Iban word for returning home.

A senior Iban, originally from Rumah Manah but today a Malaysian citizen, conveyed during a visit to Kalimantan how after emigrating to Sarawak he was employed by British soldiers to fight the Indonesian army. Ironically, he was later awarded honorary military insignia by the Malaysian state for his courage in the fighting. ${ }^{16}$ Iban fighting for the

15 Stephen Kalong Ningkam was an influential politician and leader of the Sarawak Nationalist Party (SNAP). He was of mixed Iban/Chinese descent and from the Katibas region in Sarawak just opposite the border. He held the position as Chief Minister from 1963 to 1966 and drew his main support among Iban communities in the First and Second Divisons. His younger brother, a police sergeant stationed at

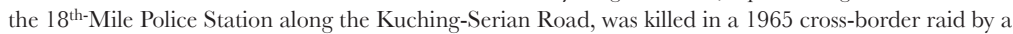
group of TNKU guerrillas from Indonesia (Tan 2008:14-6).

16 See also Christine Padoch, who has noted similar emigration of Kalimantan Iban from the upper Kapuas River into Sarawak during the Confrontation in order to escape harassment by members of the Indonesian military (Padoch 1982:31). 
Indonesian army received similar honorary insignia and documents. For example, in Rumah Manah, four men were given medals of bravery (pala berani) by the local army commandant, but despite such recognition of their national loyalty, they have all since migrated and settled in Sarawak.

Communities situated close to the border were particularly vulnerable to the fighting. Brigadier Robert Gurr, the commanding officer of a company from the New Zealand Commonwealth forces stationed across the border in the Lubok Antu area (Second Division of Sarawak) reported:

Those who lived in proximity to the border were sandwiched between hostile forces. Mistaking the identity of groups of Dayaks was always a problem, particular those who ran the gauntlet of border crossing. [...] (Gurr 1995:109).

Several longhouses in the Badau and Lanjak area were hit by mortar fire from the Commonwealth forces, and the Indonesian army relocated entire longhouse communities further away from the border (just as the Dutch had attempted to do a century earlier). Senior inhabitants in the area tell how the heavy British bombing of the Indonesian encampments in the border hills largely prevented locals from going to the forest and harvesting their hill rice. This led to a scarcity of food and subsequent hunger. ${ }^{17}$ The military further employed many locals as forced labourers for carrying supplies of rice and ammunition from camp to camp along the hilly front line. Such incidents hardened local sentiments against military and government. As recounted by two senior Iban:

Soldiers patrolled the border, and as Indonesian citizens, we had to help our forces carry the soldiers' rice, their bullets (angkut beras angkut peluru) and other supplies. We suffered deeply (sangat menderita); we could not go to our rice fields, could not make gardens, could not do anything. ${ }^{18}$

Day and night, the British bombs hit our fields at Perayung hills trying to hit the [Indonesian] army dugouts in the hills. Almost 300 bombs

17 For detailed accounts of the numerous clashes between the Indonesian army and Commonwealth troops in the Badau-Lubok Antu area see Gurr 1995:85-102.

18 Personal interview, Iban patih, Lanjak, 23-3-2007. 
were dropped in this area, which made it impossible to clear the land for making fields. ${ }^{19}$

What characterised these years of Confrontation was an unrelenting atmosphere of insecurity. Combatants from each side of the border continuously carried out armed raiding back and forth across the forested boundary line with local communities caught in the middle. While the relationship between the Indonesian military and the border population often were strained and violent, the Commonwealth troops on the opposite side of the border developed a more benign approach to win the 'hearts and minds' of every border community by supplying food provisions and medical services (Smith 1999:7).

\section{OPERATION DESTRUCTION: COUNTERINSURGENCY AND ANTI- COMMUNISM}

These low-impact cross-border incursions lasted until 1965, when General (later President, 1967) Soeharto came into power after crushing a failed coup attempt by leftist troops from Soekarno's presidential guard. ${ }^{20}$ The new right-wing Soeharto regime quickly began to establish relations with Sarawak and initiated a new strategy of 'peaceful confrontation' (Weinstein 1969). An official ceasefire was agreed upon in early 1966, and a memorandum of understanding was signed in August 1966 in Jakarta. A joint boundary committee was formed with members from both sides. The main purpose was to define the exact borderline between the two countries. A year later, the work of the committee culminated in the signing of the 1967 Basic Agreement between Malaysia and the Republic of Indonesia that formally recognized the border between the two nations. Additional meetings were held in 1972 in Kuala Lumpur and again in 1973 in Jakarta to plan joint survey operations.

The Soeharto regime quickly established a firm military presence in West Kalimantan, including the remote borderlands of Kapuas Hulu.

\footnotetext{
19 Personal interview, Iban headman, 22-6-2007. See also Pugsley (2003:314-5) on the Commonwealth troop build-up on the Sarawak side of the Perayung hills and their bombing across the border. The hilly borderland is still scored by trenches and littered with unexploded bombs.

20 The ambiguous manoeuvering behind this coup attempt that later led to the overthrow of President Soekarno is still highly controversial.
} 
Consequently, all Indonesian military support of the TNKU was withdrawn. As stated by a former TNKU veteran living in Lanjak:

The Malaysian soldiers sent us a letter saying 'we are not looking for war but peace' (bukan cari peperangan tapi cari damai). So we went to the border in the Kedang area for a meeting with the Malaysians. Afterwards all the volunteers were called (dipanggil) to Semitau, and in 1965 all volunteers were dismissed (sukuan dinyatakan bubar). Those who still felt strong went straight into (teruskan ke tentara) the army as regular soldiers or joined other groups fighting the Sarawak government. The rest of us were given a letter of passage and could return home. ${ }^{21}$

After Soeharto took power, Indonesian politics altered course, resulting in the launching of an anti-Communist campaign, and an uprooting of what the military labelled 'Communist insurgents' along the border. ${ }^{22}$ Subsequently, from the mid-1960s until well into the 1970s, guerrilla warfare took place in the West Kalimantan borderland between Communist guerrillas (former allies of Soekarno's war against Malaysia) and the Indonesian army. ${ }^{23}$

The Indonesian army initiated a series of so-called 'counterinsurgency' operations along the border known by the overall name of 'Operation Clean Sweep' (Operasi Sapu Bersih) (Rachman et al. 1970:239-301). To begin with, military operations were mostly concentrated in the lower district of the province with its large Chinese population. In the late 1960s and early 1970s the military focus first shifted towards the more remote and rugged inland border areas like that inhabited by the Iban. ${ }^{24}$ The inland district of Kapuas Hulu (together with those of Sanggau and Sinang) were labelled the 'eastern sector' by the military command (Soemadi 1974:94). As part of the 'Clean Sweep' campaign, the military in 1968 embarked on 'Operation Destruction' (Operasi Penghantjuran) in the eastern sector, the purpose of which was, as the name implies, a

${ }_{21}$ Personal interview, ex-TNKU, Lanjak, 23-7-2007.

${ }^{22}$ The term 'insurgents' is here deliberately place within quotation marks, as it is important to remember that the term carries a negative conation. It labels the rebels 'cause as illegitimate, whereas the rebels themselves see the government authority itself as being illegitimate.

23 This was part of a larger coordinated military campaign against the 'Communist insurgents' launched by the Indonesian and Malaysian security forces.

${ }_{24}$ This major military operation was carried out in three periods, Operasi Sapu Bersih I (1967), II (1967-1969) and III (1969-1970). See Soemadi 1974. 
total annihilation of insurgent activities in the borderland. The part of the sector inhabited by the Iban was given special attention (Rachman et al. 1970:295-7). The same year the Indonesian military commander in West Kalimantan, Brigadier General Witono, claimed that as many as 5,600 regular troops were engaging the insurgents in the province (Kroef 1968:263).

The Indonesian New Order government saw indigenous minorities, especially borderland communities like the Iban, as a possible conduit for the infiltration of foreign ideologies such as communism into the country. As a result, the military operations were carried out on two fronts. Besides direct military action against so-called insurgents, attempts were made to win over the hearts and minds of the Iban and make them into compliant citizens. The Iban long-term orientation towards Sarawak, their low level of education and lack of religion were of particular military concern.

As indicated in a historical account of the Regional Military Command in Pontianak (KODAM XXI/Tanjungpura), military leaders were well aware of the strong kinship bonds between Iban in Kalimantan and those in Sarawak and their ongoing socio-economic interaction (Rachman et al. 1970:295). This interaction was acknowledged as partly a consequence of historical processes and shared ethnicity, but also a result of the particularly low level of development on the Indonesian side of the border. Military accounts emphasized how compared to Sarawak the Iban in Kalimantan were still relatively backwards (terbelakang), both materially and intellectually. As stated in one military account:

Iban awareness of political engagement is not yet developed (belum madju), the necessities of daily life are more primary for them, they therefore easily fall under the influence (pengaruh) of the Chinese communists (Tjina komunist) and they are easily influenced by agitation and manipulation (dihatut dan diperalat) of their (the communists') politics (Rachman et al. 1970:319).

According to the military, one consequence of the above-mentioned circumstances was that the majority of Iban communities generally took an uncooperative stance towards the Indonesian military operations in the area (Rachman et al. 1970:295, 319). The Indonesian military was aware of the possibility of Communist infiltration among the border Iban, 
as coordination meetings in September 1969 with Sarawak's Special Branch (security police) - now allies of the Indonesian army, conveyed information that several Sarawak Iban had already been influenced by Communist propaganda. ${ }^{25}$

The KODAM XXI accounts stated that the main objective behind Maoist/Communist warfare strategy was to infiltrate the common people. As in Sarawak, also in Kalimantan: the Iban and Chinese communities had a long tradition of socialising, trade and intermarriage; consequently, the Iban were particularly prone to Communist infiltration and not to be underestimated (Rachman et al. 1970:320-1; Soemadi 1974:96). This also included the ethnic Chinese communities who largely were labelled as Communists and seen as a potential security threat. Unable to achieve the status of Indonesian National Citizens (Warga Negara Indonesia, WNI,) they were seen as foreigners (Warga Negara Asing, WNA) and were especially vulnerable to military harassment and forced expulsion (Tempo 1974a, 1974e). Many ethnic Chinese civilians were living along the border in towns like Nanga Badau and Lanjak, and the Indonesian Army was supposedly afraid that these communities would support the insurgents with supplies. In order to prevent these Chinese communities from siding and interacting with the Communists, the Army in 1970 relocated approximately 70,000 ethnic (Hakka) Chinese, removing them from the border districts of Sanggau, Sintang, and Kapuas Hulu (Soemadi 1974:91). In other parts of the province (especially the lower Sambas and Bengkayang districts), the military directly encouraged local Dayaks to engage in violent expulsions of Chinese farmers; this led to massacres. Jamie Davidson and Douglas Kammen note how the 'Dayaks' were encouraged by the Indonesian military authorities to engage in violence and headhunting (ngayau) (Davidson and Kammen 2002:17-8). Such violent outbreaks against ethnic Chinese, however, did not take place in the borderland inhabited by the Iban.

Five years previously, a similar attempt to relocate (Hakka) Chinese communities situated on the Sarawak side of the border was carried out by the Sarawak government. This operation was code named 'Operation Hammer' and resulted in the resettling of more than 8,000 Chinese

${ }_{25}$ The Sarawak Special Branch was originally created in 1949 in order to collect intelligence on various subversive activities and secessionist movements including those inspired by Communism. This special unit of the police later came to play an important role in curbing the spread of Communist 'propaganda' in the 1960s and 1970s (Porritt 2006). 
to temporary, wire fenced 'security concentration centres' away from the border in so-called 'controlled areas' (Siburan, Tapah and Beratok) (Yong 2006). Like the Indonesian government, the Sarawak government believed that among the ethnic Chinese communities were subversive elements that were actively supporting the 'Communist terrorists' in their cross-border raids (Tan 2008:24-5).

Although much military effort was put into countering the Chinese influence, through relocation on both sides of the border, less militaristic attempts were carried out in order to shift the loyalty of the Kalimantan Iban communities. In 1971 Brigadier General Soemadi, a leading military general from the provincial Military Command stationed in the border area, emphasized that Communist infiltration among the border communities could not be solved without immediate action to develop the area. According to Iban statements, Brigadier General Soemadi often expressed sympathy for the difficult situation of the border population. His long presence in the border area resulted in various closer relationships with the Iban. A highly placed member of the local Iban elite claims that Major General Soemadi, while stationed in the border area, even married a close cousin of his from Merakai Panjai (now Puring Kencana).

In a 1971 interview with the Indonesian news magazine Tempo magazine, Soemadi stated that the border area was very underdeveloped (sangat terkebelakang), the local farming techniques were still that of swidden agriculture, and people's health condition and education were very weak (sangat rendah). Furthermore, the problem of cross-border shared ethnicity (hubungan darah, literally 'shared blood') made it extremely difficult to control the movement of these populations and to determine their exact nationality, as many were born across the border in Malaysia (Tempo $1971 \mathrm{a}) \cdot{ }^{26}$

In order to solve the problem of underdevelopment (problema pembangunan) and lack of national consciousness, the military implemented several measures intended to help raise the local standard of living (Soemadi 1974). In 1974, a team from the National Development Planning Agency (BAPPENAS) visited the border region to assess future development initiatives; they found six areas in special need of development projects (proyek khusus), two of which were Nanga Badau and Nanga

26 Bear in mind that newspaper and magazine articles dealing with the 1960s and 1970s 'Communist insurgency' were by and large military propaganda. 
Kantuk in the Iban inhabited part of the borderland. ${ }^{27}$ According to Governor (Colonel) Kadarusno, approximately Rp24 billon (US\$58 million) was to be used on border development in the next five years (Tempo 1974c, 1974d). As stated by Nancy Peluso and Emily Harwell, such development programs were a well-integrated strategy in military counter-insurgency tactics (Peluso and Harwell 2001).

In the Lanjak area, the military invested much energy in developing areas for irrigated rice fields or wet rice (sawah) cultivation as an alternative to swidden cultivation in the hills, which was perceived as destructive and primitive (Soemadi 1974:140-5; Tempo 1971 1a). Furthermore, by encouraging the growing of irrigated rice in the valleys, the military hoped that Iban communities would move away from the hilly areas closer to the border and settle out of reach of the insurgents. This only partly succeeded, and most communities remained in the hills. Davidson and Kammen, for example, describe how the Indonesian government invested large sums in similar projects throughout the province as part of what was known as the 'road and rice' campaign (Davidson and Kammen 2002:25). Only a few Iban embraced this new possibility as it meant leaving their customary land, over which they had traditional user rights, and moving to areas already occupied by other Iban and Maloh communities. ${ }^{28}$ In the 1920 s the Dutch had used a similar tactic and constructed irrigated rice fields in the plains, meaning that the communities who were forcibly moved at that time already claimed most land suitable for this kind of cultivation. ${ }^{29}$ In addition, the land converted by the military was generally not suited to extensive wet rice cultivation, and the yield quickly fell to below what was produced through swidden farming.

The military were convinced that in order to improve Iban sentiments towards Indonesia, programs of social education in loyal and appropriate behaviour were needed in addition to development projects (Soemadi 1974:96-9). Social education programs included everything from learning catchwords, symbols, and acronyms associated with the nation to courses in health promotion and appropriate lifestyle (discouraging longhouse living, for example). The Regional Military Command

\footnotetext{
${ }_{27}$ The four other areas were Sajingan (Sambas district), Balai Karangan (Sangau district), Senaning and Sungai Antu (Sintang district) (Tempo 1974d).

${ }_{28}$ Growing hill rice plays a vital role in Iban social and spiritual life, and many of the more conservative Iban are extremely reluctant to give up this form of rice cultivation.

29 See W.H.E. Scheuer, Memorie van Overgave van de afdeeling Sintang, Juli 1932, Koninklijk Instituut voor de Tropen, No. 997. ARA.
} 
stated that: 'Their (the Iban) national attitude (sikap nasional) is indeed very low (tipis sekali), you could even say it is not there at all' (Rachman et al. 1970:295). In an attempt to heighten national loyalties and promote state ideology, the military began to construct schools and undertook mass education (pendidikan massa) (Soemadi 1974:104). Several hundred soldiers were posted as teachers along the border (Davidson 2002:198). Recalcitrant Dayaks like the Iban who were classified as particularly 'difficult' subjects (klasifikasi berat) were forced to endure 'mental education' (pendidikan mental) in order for them to choose the 'right' side and oppose the enemy (Soemadi 1974:124). The Iban were taught the national ideology of Pancasila ${ }^{30}$ in order to develop their understanding of the unified nation-state (Kesatuan Negara). ${ }^{31}$ Threatened with being labelled unpatriotic, the Iban were persuaded to proclaim their allegiance to the Indonesian state ideology. As recollected by a senior Iban:

I was still young and there were no real schools in the area [Ulu Leboyan] at the time. I remember how the officers from the military camp across the river came to the longhouse every day in the evening when people returned from their fields. They brought books, and we all had to sit on the open veranda (ruai) and listen so we could become good citizens (warga negara). I did not learn to speak Indonesian (Bahasa Indonesia) before the soldiers arrived. ${ }^{32}$

The first principle in the national ideology states the importance of religion, or more specifically, the belief in one God (monotheism). As an Indonesian citizen, you are required to be a member of one of the five state approved religions (Islam, Catholicism, Protestantism, Hinduism or Buddhism). As stated by Brigadier General Hartono: 'I don't care what religion they have; the main point is that they have a religion (beragama)' (Tempo 1974b).

This posed another problem for the Iban. The more conservative Iban living in the hills along the border had been very reluctant to adopt the preaching of the early Christian missionaries and, unlike other

\footnotetext{
3o Pancasila relies on five principles; 1) Monotheism (Ketuhanan), 2) Humanism (kemanusiaan), 3) The unity of nationalism (kebangsaan), 4) Democracy through representative government (kerakyatan), 5) Social justice (keadilan social).

${ }^{31}$ For a more detailed discussion of national schooling in the borderland and the paradoxical outcomes, see Eilenberg 2005.

$3^{2}$ Personal interview, Ulu Leboyan 30-5-2007.
} 
groups such as the Maloh, they had felt no need to convert. In 1908, Dutch Capuchin missionaries set up missions in the Iban-dominated town of Lanjak at the border. ${ }^{33}$ These missions were expected to have a 'civilizing' (beschaving) influence on the Iban, lifting them up to a higher living standard (menschwaardig bestaan) (Anonymous 1921:58). The missions were temporarily closed in 1915 and completely abandoned in the 1920 s as the Iban refused conversion, and the missionaries consequently moved to the ethnic Maloh stronghold in Benua Martinus (Buil 1921). ${ }^{34}$ As reported by the Capuchin Father Ignatius. 'The Iban were not yet mature enough for schooling' (De Ibans zïn nog niet rïp voor school). Ignatius here indicated that he thought the Iban had not yet reached a sufficiently advanced stage of intellectual or emotional development. ${ }^{35}$ The lack of success was also placed squarely on the shoulders of the government (bestuur), despite the efforts of the missionaries.

They (the missionaries) would have succeeded among the Batang Lupars if the government had given more support. The government is taken to task; a thorough and wise government brings betterment and progress, but a weak and vacillating one does not lift the poor Dayak up. It is hoped that a new Resident will support the mission more.

Ignatius goes on to say that earlier on the Dutch government pushed for the mission to begin work in order to help the government with its efforts of pacification, but at present their help is not needed and the government advises the mission to leave the task of civilizing the Iban to the government. At the time the mission was set up, the military still had little influence on the Iban, and the mission had to come and help among that murderous people (dit moordzuchtige volk). There were many severed heads being brought in then (Menig gesneld hoofd werd in die dagen nog in triumf binnengehaald). He asks rhetorically, why did the then-government officer provide protection and an armed guard when the first missionaries ventured among the notorious (beruchte) Iban? In answer, the unnamed goverment official knows it was not advisable to go alone and unarmed

33 See 'De vestiging van de nieuwe missiepost te Landjak, Zondagsblad 1909', No. 2741, Verzameling Losse Archivalia, Katholiek Documentatie Centrum, Nijmegen.

34 See also Kroniek over de Missie van Borneo, samengesteld door Valentinus, 27-1-1954. Kapucijnenarchief, Archivum Capucinorum Hollandensis (ACH), 's-Hertogenbosch, Netherlands.

35 Letters from Lanjak 1908-17, to Pater Provinciaal. 30-9-1912, P. Ignatius. Kapucijnenarchief, Archivum Capucinorum Hollandensis (ACH), 's-Hertogenbosch, Netherlands. 
amongst that people (dit volkje). But, he says, our missionaries are apostles of peace and did not rely on the power of weapons. He adds that the missionaries went unarmed to the heathen (heidensche) headhunters, trusting only in help from Above (Anonymous 1921:59-60).

At the onset of militarization in the 1960s, the majority of the majority of the Iban still retained their traditional beliefs and were consequently portrayed by state authorities as lacking religion. This was of special concern for the military, as it was believed that the Iban, like other conservative Dayaks lacking a recognized religion, would be especially susceptible to the teaching of the godless Communist insurgents and therefore more at risk of joining the Communists. In order to avoid military accusations of Communist collaboration, many Iban felt forced, at least formally, to convert to either Protestantism or Catholicism. For example, in Lanjak the military erected churches and carried out missionary work. Battalion 308 stationed in the area at the time played an especially important role. That battalion consisted primarily of Protestant Christians from the Batak region in North Sumatra. Such military involvement in civil matters was formalized in the 1980s, as the government introduced an official program of direct military development intervention called AMD (ABRI masuk desa) or 'ABRI (the Indonesian military) enters the village'. In the border area the AMD programs involved military personnel who engaged in projects such as teaching, developing rice-production schemes and the like. Although development was the official rhetoric behind the AMD programs in the borderland, it was primarily an attempt to prevent the local communities becoming influenced by foreign ideologies.

Despite considerable efforts by the military to win over the minds (and souls) of the recalcitrant border communities, reorientation of national sentiments was never successful among the Iban. Iban attitudes towards the Indonesian state remained ambivalent, partly due to military brutality and partly to the long Iban history of autonomy and close crossborder ties.

\section{THE PARAKU: INSURGENTS OR LIBERATION ARMY?}

During both Konfrontasi and the subsequent Communist uprooting, the majority of border communities avoided direct involvement in the 
conflicts. However, a group of locals (mostly Iban) were drawn into the conflict between ABRI and the left-wing rebels (predominately Communist). The rebels active in the Kapuas Hulu borderland were known as the PARAKU, an acronym for the North Kalimantan Peoples' Army (Pasukan Rakyat Kalimantan Utara). ${ }^{36}$

The PARAKU consisted of a mix of former TNKU rebels, Sarawak Chinese Communists, and a small number of Iban and other Dayaks (Soemadi 1974; Sulistyorini 2004). The large majority of the PARAKU was Sarawak Chinese, many from the Sarawak Communist Organization (SCO), which had supported the TNKU since the Confrontation in the early 1960s. Several Iban interviewed in Lanjak further recounted how a small group of Sarawak Iban actively joined the PARAKU ranks. One Iban man in particular, Ubong from the Rejang area in Sarawak, was described as main figure and deputy commander of the PARAKU rebels in the Kapuas Hulu area. According to Fujio Hara, Ubong was appointed deputy commander of the PARAKU rebels in the late 1970s (Hara 2005:502). Ubong supposedly brought both his wife and children with him across the border. Ubong's jungle skills and bravery quickly made him a local legend in the borderland. Moving like a shadow in the forest, killing many Indonesian soldiers without being shot or captured himself, he was believed to possess supernatural powers $\left(\right.$ sakti) ${ }^{37}$

The PARAKU rebels were a mix of mostly young men and women, often husband and wife, fighting side by side. ${ }^{38}$ Their prolonged stays in the border region often cut off from supply lines in Sarawak meant that many of the PARAKU units began making camps that were more permanent. Here they engaged in the cultivation of rice and vegetables in garden plots in the remote upriver interior along the border. Growing their own rice and vegetables played a major role in the endurance of the rebels. However, by clearing fields in the forest they also became more vulnerable to bombing by Indonesian planes cruising the border hills.

The main ideological goal of the PARAKU was, like that of the former TNKU, to liberate Sarawak from the Malaysian state. Consequently,

\footnotetext{
$3^{6}$ The rebels were divided into two groups concentrating on different parts of the West Kalimantan-Sarawak border. PGRS/Paraku (Pasukan Gerilya Rayakat Serawak/Pasukan Rakyat Kalimantan Utara) (Davidson and Kammen 2002:3).

37 Personal interview, Lanjak, 23-3-2007.

$3^{8} \quad$ Lumenta (2005:15) notes how the female Communist rebels were known as Pasukan Amoy (Amoy troops among the locals. 'Amoy' is an Indonesian form of address given to a Chinese girl (in some regions only). In its original meaning, 'Amoy' denotes a Chinese dialect.
} 
fighting was primarily oriented towards Sarawak, but the military cooperation between Indonesia and Malaysia and the heavy engagement of the Indonesian army in the border area meant that the PARAKU was forced to fight them as well. ${ }^{39}$ Many of these PARAKU rebels, originally volunteers during the previous period of Konfrontasi, were trained and armed in the early 1960s by the Indonesian Special Forces, RPKAD, in camps along the border. The PARAKU therefore found it advisable to establish guerrilla base camps in the rugged and heavily forested Kalimantan borderland, from which they could launch attacks into Sarawak.

In an interview with a former RPKAD captain named Untung Suroso, Conboy describes how three RPKAD military trainers in the early 1960s were parachuted into the border village of Nanga Badan (misspelling of Nanga Badau) in West Kalimantan. These three soldiers supposedly trained 300 locals in guerrilla warfare. This group of volunteers was later divided into two groups lead by two army lieutenants named Kentot Harseno and Mulyono Soerjowardojo (Conboy 2003:95). As recounted by an Iban patih in Lanjak:

In 1962, I was still in school but I remember I saw them [TNKU] practice together (latihan sama-sama) with the RPKAD Special Forces. In Lanjak, there were three military posts and three barracks and the Chinese from Sarawak and the volunteers was given weapons and food by the Indonesian government. I remember the TNKU commander in that times his name was General Peng. He was from RRC (Republic Rakyat Cina/ People's Republic of China, he wore a broad hat with 'Peng' written on it, and there was a red picture of Mao. He was a smart person (orang pintar). On every August the $17^{\text {th }}$ [ndonesian Independence Day] he held a ceremony and gave a speech (ceramah) of encouragement to his people (anak buahnya). General Peng was fluent in Indonesian, English, and Iban. ${ }^{40}$

Whether the above statement is entirely accurate is difficult to assess; local rumours say that instructors from the RRC entered Kalimantan during this period, but it is more likely that the General Peng mentioned here was a Sarawak Chinese trained in China. A 1973 classified CIA

39 For a detailed description of the general political dynamics in West Kalimantan during the era of militarization, see Davidson 2002.

$4^{\circ} \quad$ Personal interview, Iban patih, Lanjak, 23-3-2007. 
intelligence report states that Peking provided moral support to the insurgents, although there was no confirmation of Chinese military personnel taking an active part in the training of the insurgents within Kalimantan or Sarawak (CIA Intelligence Report 1973). Like the PARAKU, many of the TNKU soldiers used an alias. However, in his account of the military involvement in fighting the PARAKU, General Soemadi mentions the 1971 surrender of a rebel leader named Sim Kiem Peng from the PARAKU Unit Satuan 330 who operated in the Lanjak area (Soemadi 1974:130-1).

During military training, socializing between the volunteers and Iban inevitably occurred. At that time, the army actively encouraged Iban communities to provide supplies of rice and meat and logistical support in form of longboats to transport the volunteers and their supplies upriver to the 'front' along the border.

The sudden change in Indonesian politics from being pro-Communist under Sokarno to anti-Communist under Soeharto deeply confused many Iban, and they became increasingly unsure about who was friend and who was enemy. As an elderly Iban informant in Lanjak put it:

Old allies suddenly became enemies when the Communists were forced into the jungle in 1965 by Soeharto and returned as the PARAKU a few years later. The PARAKU were well trained (melatih), because those who trained them were Indonesian Special Forces (Pasukan Khusus, RPKAD). But after being trained they separated (pisah), friends became enemies (kawan jadi lawan). This is the problem (ini masalahnya). ${ }^{41}$

Another peculiar twist adding to this confusion erupted in 1969 when Brigadier General Witono put forward allegations that some segments within the West Kalimantan Army Command supposedly supported the PARAKU. In the subsequent period, several Army officers were arrested (Kroef 1970:49).

Caught in the struggle between the two conflicting parties, the Iban were often forced to choose to be loyal towards one, leading to violent reprisals from the other. Some Iban men developed friendships with PARAKU rebels (several of whom were Iban) who came to their villages asking for supplies, which were often provided in return for helping out

${ }^{11} \quad$ Personal interview, Lanjak, 23-3-2007. 
in the rice swiddens. If detected by the Indonesian army, such interactions with the 'enemy' were severely punished. Meanwhile, other Iban men were employed as scouts for Indonesian army patrols to track down the very same people, or served as intelligence gatherers at the village level.

Senior inhabitants of Rumah Manah describe the shifting relationships with both the ABRI and PARAKU in the borderland during the 1970s. One of these, Mandau, who at the time of the PARAKU was in his mid-thirties, speaks of how Chinese Communists often visited his longhouse, asking for food. ${ }^{42}$ Not having any grudges against these people, who often spoke Iban very well, the Iban often provided the food. The PARAKU further entered into different kinds of relationships with the Iban, such as trading medicine and buying domesticated pigs and chickens from the longhouse inhabitants. ${ }^{43}$ Furthermore, Mandau tells how several people in the longhouse were cured of illnesses by the use of acupuncture administered by the PARAKU:

If the PARAKU came to the village [longhouse], we would give them food, because we are human beings, are we not? If we gave food, the government suspected us (dicurigai) of being Communist collaborators, but it was not our intention to be disloyal to the government. We felt squeezed (terjepitlah) in between the two[Indonesian forces and PARAKU]. ${ }^{44}$

In many instances, the insurgents enjoyed a closer relationship with the local population than the Indonesian military did. The latter relationship was more troubled because the military often forced the locals to perform unpaid labour (Davidson and Kammen 2002:30). An article from a 1971 issue of Tempo magazine describes how the PARAKU operations in the border area were made possible through the PARAKU's extensive knowledge of the border area, its population, language, and customs (Tempo 1971b).

During military operations against the PARAKU carried out by the Malaysian forces, various documents were obtained, such as Communist publications in the Iban language, Iban dictionaries and notebooks. These documents were indications that the PARAKU were actively try-

$4^{2}$ Personal interview, Ulu Leboyan, 13-11-2003.

43 See also Soemadi 1974:94.

44 Personal interview, Iban farmer, 10-4-2007. 
ing to learn Iban (Porritt 2004:164; Rahman 1972:15). One extract from captured letters reads:

Regarding what we need, please get me some Mao badges, Mao's Quotations, Mao stamps, and so on. We also need Iban books, an Iban dictionary, a Chinese dictionary, the various new and old laws and ordinances of the puppet regime, materials concerning the history, geography and people of North Kalimantan, and shotgun cartridges (Rahman 1972:15).

The Malaysian government's anxiety concerning the so-called expanding 'Communist threat' in Sarawak is most evident in a White Paper published in 1972 (Rahman 1972). The White Paper quotes a document of the Sarawak Communist Organization (SCO) dated December 1967 that supposedly details the SCO plan for armed struggle:

In view of the disadvantageous political situation in Indonesia, our Organization quickly withdrew our comrades to the border area in two batches; one retreated to the West and the other to the East. [...] By going to the border area, we will be able to set up bases with excellent topographical conditions and launch a long-term guerrilla war. We will gradually penetrate into the country with the border area as the stepping stone and then surround the cities from the rural areas, occupy the whole country and finally take over the power of Government' (Rahman 1972:2). ${ }^{45}$

While the Iban acknowledge some interaction with the PARAKU, Mandau, cited above, also talks about young Iban men earning a salary by helping the Indonesian military track down these same insurgents. ${ }^{46}$ One example was that of an Iban man from the Lanjak area who worked as an intelligence-gatherer under the cover of ngayap, an Iban term for young men engaged in finding a wife. Such courtship pursuits often involve the bachelor visiting many different communities, which is a good cover for gathering intelligence. Similar examples of Iban involvement in the uprooting of the PARAKU have been noted by other scholars like

45 It is important to remember that this White Paper was part of the Malaysian government's antiCommunist propaganda.

$4^{6} \quad$ For similar statements about Iban communities in the subdistrict of Empanang, see McKeown 1984:105. 
Pirous (2002) and Lumenta $(2001,2005)$ in their research on the Iban living along the Embaloh River.

Adding to the ambiguousness of this case, two local men who during Konfrontasi were hired by the military to become TNKU volunteers were later employed by the same military command to track down the PARAKU (several of whom were former TNKU). One group of local scouts mostly consisting of former TNKU volunteers was stationed in Lanjak and assisting the military to track down the PARAKU. ${ }^{47}$

The Javanese soldiers who came to the border could not find their way (tidak tahu jalan tidak tau apa) in the forest where the PARAKU were operating. They did not know anything. We were always brought as guides to show the way although many did not want to help the soldiers. My company was named 'White Bear' (Bruang Putih) and when we guided the soldiers, they never met the PARAKU, but when the soldiers went alone they often clashed. The soldiers were confused (heran) and asked why is it that when we go by ourselves we meet them (the PARAKU) by chance, but if you join us we never meet. Maybe you have some kind of magic (mungkin Bapak punya Ilmu) the soldiers said. ${ }^{48}$

This is a well-known secret (rahasia). Before, the people who are now called PARAKU used to be together with us (the former TNKU), but then we were separated (berpisah) in 1965 and1966. After they left us and went to the jungle, they sent us a letter saying 'my friends we leave you all because Sarawak is now part of a independent Malaysia, but we will stay in the jungle and keep fighting, and if you are our friends join the soldiers but do not shoot at us. We will not bother you either; this is our promise'. They kept their promise (janjinya); we were never shot, although the soldiers walking behind us sometimes were fired upon from the jungle. When we arrived at a PARAKU camp they had just left and we only saw their wet footprints on the stones (bekas PARAKU di batu masih basah). The PARAKU knew the jungle (pandai masuk hutan mereka); they had already been here for a long time. Think about that (cobalah). ${ }^{49}$

47 In the Lanjak area, several army units used Iban 'scouts,' such as Battalion 323 (Galuh), 324 (Siluman Merah), 327 (Brajawijaya), and 642 (Kapuas). For examples of military certificates given to local Iban recruited as 'scouts' see Figures 21, 24 and 25.

$4^{8}$ Personal interview, local scout 23-7-2007.

49 Personal interview, Lanjak, former local scout, 23-7-2007. 
Iban involvements with the Indonesian army have later been recognized by local and central government as examples of acts of loyalty towards the Indonesian State (Japari 1989:11). War veterans further received official certificates signed by President Soeharto and were promised a lifelong war pension: ${ }^{50}$

After the insurgency, we were acknowledged (diakui) as war veterans (anggota veteran) but never received our pension. Several times we went to the Kodim office [District Military Command] but we never got an answer. Some of us even went to Pontianak and Jakarta but it was no use. We were very disappointed, as no one seemed to respect those of us who went to war to defend the country (membela Negara). We were not even given one cent in reward (tidak ada satu pun, sepersen pun imbalannya). ${ }^{51}$

The flexible attitude towards the two fighting parties was not without a certain risk. If cooperation with the Communists was detected by the military, it could have serious repercussions for the Iban communities. There are several examples of how the military bombed longhouses as punishment for such arbitrary loyalties (Lumenta 2005; Pirous 2002). Afraid of military punishment, many families moved to Sarawak, including entire longhouse communities. Close to Rumah Manah was a longhouse of thirteen families who moved to Sarawak overnight in 1968 leaving everything behind, even treasured heirlooms (pusaka) such as old brass gongs. Rice was left on the plates, pigs and chickens still roamed under the house. The group followed the Leboyan River until they reached Sarawak and never returned to get their belongings. The community supposedly decamped in order to escape severe military punishment for harbouring PARAKU insurgents. As one Iban informant stated, 'they cannot return permanently because they are now [citizens] under another flag (mereka sudah bendera yang lain)' ${ }^{52}$

Just across the border in Lubok Antu, several Iban leaders was arrested and accused by Malaysian Forces of supplying food and intelligence to the PARAKU. In 1968, ten Iban headmen were arrested in Lubok Antu (Porritt 2004:164). In the subdistrict seat of Lanjak, there were several cases of Iban being tortured or executed for their alleged

5o See Figure 20.

51 Personal interview, Lanjak, Iban war veteran, 23-7-2007.

$5^{2}$ Personal interview, Lanjak, 14-7-2007. 
cooperation with insurgents. Many stories of military brutality against civilians still flourish in the borderland, some better substantiated than others. Two episodes that were verified by all my informants were the accounts of Rantai and Ranau. These accounts in many ways stress the difficult situation that the Iban leaders were confronted with especially in their ambivalent position between the military and the PARAKU. ${ }^{53}$

In 1966, a group of heavily armed PARAKU rebels ambushed an Indonesian army patrol near Lanjak. The patrol was taken totally by surprise, and several soldiers were instantly killed, while only one rebel was hit before the PARAKU again withdrew towards their hideouts in the forest. One Iban man named Rantai was subsequently arrested and accused of being involved in the attack by supplying the PARAKU with intelligence. Rantai was taken back to Lanjak, where he was executed and hung in a tree in a rattan cage. The cage was shot full of holes and left on display. ${ }^{54}$

Ranau was the headman of an Iban longhouse near Lanjak. Since the early encampments of the PARAKU in the borderland, before the strong military presence, Ranau had engaged in a working relationship with the PARAKU. They helped him in his rice fields, sowing and harvesting, and did other kinds of manual labour in exchange for food and shelter in his field huts. This relationship evolved into friendship, and Ranau became blood brothers (bekempit darah) with two PARAKU men operating in the area. According to Iban customary law, taking a blood oath means that you are mutually responsible for each other's safety; you are friends until death (teman sampai mati). As the military presence grew stronger in the early 1970s, rumours of Ranua's relationship with the PARAKU went from mouth to mouth (dari mulut ke mulut) and finally reached the ears of the Indonesian military commander. Ranau was consequently arrested and tortured (disiksa) in public. He was submerged in the small river running through Lanjak for hours and beaten with rifles. The commander of the military company stationed in Lanjak supposedly announced in public that 'if he [Ranau] can catch the PARAKU, behead (memenggal kepala) them and bring their heads he will be free to go, if not he will go to jail until he dies'. Ranau supposedly felt there was no other way out than to follow this command; along with two other Iban,

53 The military policy of intimidation and violence was also widely felt among other Dayak communities living along the lower parts of the border. See, for example, Peluso 2005:120-1).

54 Personal interview, Lanjak, 9-6-2007. 
armed with military rifles, he went to the forest and after a week he returned with the heads of two PARAKU rebels. Both of these men were working under the command of the General Peng mentioned earlier. The two PARAKU rebels were not killed by Ranau but by two of his followers, although he was the one who gave the order. Ranau was later given the rank of local war commander and received a military pension for his deeds. ${ }^{55}$ This incident created great internal condemnation, as breaking a blood bond is a great sin (berdosa besar) that was and still is among the greatest Iban taboos. Several senior inhabitants of Lanjak said, 'He [Ranau] has a bad soul. It is not neutral (tidak netral jiwanya)'. During the former periods of continuous headhunting, internally and with other ethnic groups, fear of losing one's head was constant among the Iban; one way of solving this uncertainty was to make sacred pacts with other (hostile) groups. The pact was made binding when the leaders of both groups attended a blood ceremony and became one another's adopted brother. Ultimately this meant that the groups were obliged not to engage in hostilities against each other (Wadley 2001a).

These difficult years are locally referred to as the time of disruption or disturbance (musim kacau). ${ }^{56}$ For example, in 1970 ABRI initiated a massive military campaign in the Kapuas Hulu border area by having the air force bomb supposed Communist strongholds in the hills and dropping platoons of paratroopers to hunt down the PARAKU (Davidson and Kammen 2002: 31). Besides using Iban scouts, the military created so-called 'people's resistance' units, WANRA (Perlawanan Rakyat), ${ }^{57}$ whose main purpose was to form a local border defence. These groups were subject to military codes and laws. ${ }^{58}$ They mostly accompanied the soldiers, acted as forced porters on weeklong operations, and were forced to walk in front of the soldiers as shields against enemy fire. According to several informants, some WANRA members were equipped with rifles and ammunition and further received special food rations, although the majority had to do with homemade shotguns, swords and spears. The military supposedly were hesitant to arm the Iban because of their

\footnotetext{
55 Personal interview, Lanjak, 8-6-2007. This incident is also noted in General Soemadi's 1974 account of the PARAKU period (Soemadi 1974:130-1).

$5^{6} \quad$ Wadley has noted that the same term was used to describe the period of raiding and punitive expeditions during colonial times (Wadley 2004a:62).

57 The WANRA were a kind of local civil defence unit (Pertahanan Sipil or Hansip) (Sundhaussen 1982:192-3).

$5^{8} \quad$ See also Presidential Decree No. 4 of 15-3-1965.
} 
shifting loyalty. According to former WANRA members interviewed in Lanjak and Nanga Badau, each person was given a certificate in the 1970 s by the military allowing them a salary of Rp3,500 (US\$8.40) and 25 kilos of rice every month. ${ }^{59}$

Each village had its own WANRA unit that was expected to guard the village and keep it free of enemy incursions and Communist teaching (McKeown 1984:384-5). According to locals, there was a strict agreement with the military that if any regular soldiers were killed while stationed in the village area, the village head would be held solely responsible and executed. ${ }^{60}$ The function of the WANRA units on the Indonesian side of the border was in many ways similar to that of the Sarawak Border Scouts created by the Malaysian military. The Border Scouts was a semi-military unit of local volunteers (Dayaks) from the immediate border area. The unit's main purposes were to protect the local community and provide intelligence to the military (Bala 2002). But unlike the WANRA units, the Border Scouts became an effective tool in fighting the PARAKU. One reason for this was that they were genuine volunteers, well armed, and highly respected by the regular military, while the WANRA units were based on military coercion and intimidation. Generally the border population in Kalimantan had a much more strained relationship with their military than their Sarawak neighbours had with theirs.

As during the time of the Confrontation, this period of militarization of the borderland also severely affected local lives. Everyday routines were disrupted, transportation was dangerous, and limited and basic essentials were difficult to obtain. In an attempt to seal the supply lines of the insurgents, the military heavily increased its surveillance and restrictions on border trading, which had a 'dislocating effect on the border economy' (Kroef 1963:255). A five-mile-wide 'free zone' was established on both sides of the border, and only persons with special military approval could trade within this zone (Porritt 2004:157-8). The Iban, being extremely dependent on cross-border trade (especially now that the remote borderland was empty of basic goods), were severely affected:

$59 \quad$ See certificates shown in Figures 22 and 23.

6o Personal interview, Badau, 19-3-2007. 
In the 1970s every time we wanted to visit communities in other areas in the district or bring produce back and forth across the border we had to pass military posts. We were not free to move around; we were anxious (ketakutan); our backpacks (ladung) were checked (diperiksa). There were many restrictions. For example, we were only allowed to carry 5 kilos of rice, 1 kilo of sugar, and 5 matches. If we had more than that, we were accused of supporting the PARAKU. No batteries were allowed. If we were caught carrying one battery, the fine was one year in jail. Sometimes we were forced to leave everything to the soldiers. If the soldiers wanted to eat chicken, they took your chicken. They were free (mereka bebaslah) to do want they wanted. If people resisted, they were beaten. This created a feeling of hatred (rasa benci masyarakat) among communities towards the soldiers. ${ }^{61}$

Many people began to smuggle (semukil) [loan word from the Dutch 'smokkelen', to smuggle] goods like sugar and batteries over the border but if detected they were directly accused (langsung dituduhlah) of feeding the PARAKU in the forest. ${ }^{6}$

Despite the heavy militarization along the border, the Iban still maintained a certain degree of autonomy on certain local matters and did not hesitate to assert their interest and authority, even in potentially dangerous situations. For instance, at the end of the military uprooting of the PARAKU the Iban were ordered to hand in their shotguns. More or less every Iban family in the borderland was in possession of one or two shotguns, predominately used for hunting. Many of these guns were homemade, and shells were smuggled from across the border where they could be purchased at a low price. The Iban rejected this military confiscation demand outright and, led by their temenggong and patih, a group of several hundred men in full ritual regalia descended on the army headquarters. They said that they would only hand in their shotguns if the military promised to post soldiers in their swidden fields to protect them against marauding forest pigs and monkeys. The military command consequently decided not to carry out the confiscation of guns for fear of stirring up local sentiments and provoking violent confrontations. Today the five subdistricts dominated by the Iban are the only places

61 Personal interview, Badau, 21-3-2007.

62 Personal interview, Badau, 19-3-2007. 
in the district, and perhaps in the entire province, where citizens are allowed to keep their shotguns at home and not register them at the local police station (Wadley and Eilenberg 2006).

Such incidents of Iban-military confrontations convinced some factions of the military that the Iban issue was to be handled with care in order not trigger a major local uprising that would be to the advantage of the PARAKU (Soemadi 1974; Tempo 1971a). The head of the subdistrict military command ${ }^{63}$ in Lanjak outlined the delicate situation of the time in the following way:

One day my superior, a military Captain named Pak Suma, ordered me to arrest a group of local Iban who allegedly were helping the PARAKU. The Captain had a list of 60 people from many different longhouses. These people were selected based on statements from two PARAKU insurgents captured in Lubok Antu. However, I was not convinced that the information was valid enough and told the Captain that I was afraid to suspect and beat up the wrong people, because then later we would have to fight the whole community. If one Iban gets hit it could raise a war (perang) between the Iban and the soldiers, because the Iban think differently, if one gets hurt they will unite and take revenge. I suggested that it was better if we used the strategy of indoctrination first (induktrinasi dulu), and the use of force second, by explaining the PARAKU problem to the communities. ${ }^{64}$

The head of the Koramil later married an Iban woman from Lanjak and settled in the area. Several (Javanese and others) soldiers stationed in the area settled in the border area after the counter-insurgency. Some became civil servants, others entrepreneurs and storekeepers, but all became incorporated into the local border elite.

\section{ESTABLISHMENT OF A BORDERLAND ELITE}

Although a majority of the Iban kept their distance from both sides, not all Iban took such an arbitrary stance; some vigorously joined the Indonesian military anti-PARAKU campaign. Several openly expressed

63 Komando Rayon Militer, or KORAMIL.

${ }_{4}$ Personal interview, Lanjak, 9-4-2007. 
their anti-Communist sentiments by directly engaging in the fighting on the side of the military and today proudly recall their involvement in the heavy jungle warfare.

Although their shifting relationships with the fighting parties meant that Iban loyalty was often questioned by Indonesian authorities, a small handful of loyal Iban, especially those who managed to obtain good military connections, were appointed to the military rank of panglima perang (often translated as commander, but with connotations of honour and power), a position created especially for the situation. These 'commanders' came to represent local communities in their dealings with the military. They received a small salary from the government, and in return they were expected to uphold security and resolve conflict situations. ${ }^{65}$ Each subdistrict had its own panglima perang, who in turn appointed his own 'intelligence assistants' (pembantu intelijen) to keep him up to date with developments in his area. Wearing official military uniforms, the Iban commanders were given their new titles of panglima perang and certificates signed by Soeharto on 17 August 1970 during a public ceremony of Indonesian Independence Day. According to one of the Iban panglima perang, Brigadier General Soemadi supposedly said,

You have worked hard to fight the PARAKU even though you were not given a salary, so this is your salary' and he pointed towards the forest. Although we were not given any letters of proof, we still remember his words. ${ }^{66}$

Another panglima perang recalled:

Every time a new military commander was stationed in the border area we [panglima perang] were forced to take a pledge or customary oath (perjanjian adat) saying; 'We as the people of Indonesia do not help PARAKU, but Indonesia' (kami rakyat Indonesia, tidak membantu PARAKU, membantu Indonesia). This was said while stabbing a pig, as is the customary way of the Iban. ${ }^{67}$

${ }_{65}$ See also McKeown 1984:388; Effendy 1995; Lumenta 2005:17.

66 Personal interview, Embaloh Hulu, 12-6-2007.

${ }_{67}$ Personal interview, Panglima Perang, Lanjak, 9-3-2007. 
In order to instill a sense of national loyalty in local leaders, a chosen few of the panglima perang were taken to Jakarta where they were given medals of honour for good service in fighting the rebels and given an audience with the President (Soemadi 1974:163). These potent state symbols were later used as signs of authority in negotiations with various state authorities over benefits from resource exploitation.

Besides using the panglima perang, the Indonesian army also took advantage of the system of tribal chiefs, the temenggong, originally invented by the Dutch decades earlier. Like the Dutch, the Indonesian army appointed several loyal anti-Communist Iban as temenggong who could support the panglima perang in keeping Communists at bay. Since the 1960s, a local government council named MUSPIKA (Musyawarah Pimpinan Kecamatan) consisting of the subdistrict head, police and local military command began appointing the temenggong, although local communities were still allowed to nominate candidates (Lumenta 2005:17).

As I will detail later, some of these panglima perang and temenggong were eventually awarded forest concessions in the area in return for their help in uprooting the PARAKU. Today it is these men and their followers who form the base of the border elite. Besides controlling their own concessions, these Iban came to play a prominent role as points of liaison between local communities and various national and transnational logging interests. In the process, they managed to channel considerable resources their way, investing in things such as schooling for their children and various small-scale businesses ventures like shops, restaurants, and hotels. Furthermore, high-ranking military officers who after returning to Jakarta were appointed to various strategic positions within military and government circles became powerful allies for these elites.

Several of the Iban panglima perang had 'adopted' young military officers as their 'foster sons' (anak angkatnya). For example, one Iban panglima perang made the young military officer Mohamad Basofi Sudirman, who later in the 1990s became Governor of East Java, his adopted son, while another Iban panglima perang adopted a young man named Kentot Harseno. Harseno arrived in West Kalimantan in the early 1960s and became commander of a platoon in Battalion 602. In the 1970s, he joined the Army Para Commando Regiment (RPKAD). Harseno was one of the two young army lieutenants mentioned previously who was parachuted into the border town of Nanga Badau in the early 1960s in order to train locals in guerrilla warfare. The fate of the other lieutenant 
Mulyono was quite different. In 1965, post-Soekarno, he was executed by the military, accused of being a prominent sympathizer of the PKI and implicated in the so-called Communist coup (Conboy 2003:148).

After serving in the borderland and other places, Harseno became President Soeharto's military adjutant (1978-1981), commander of the Jakarta military garrison, and later Inspector General of Development (Irjenbang, 1990s). Besides these two extremely well-connected 'adoptive sons', several other prominent figures were involved in the anti-PARAKU operations in the Lanjak area. Names such as Colonel Soemadi (Governor of West Kalimantan from 1967 to 1972), ${ }^{68}$ Aspar Aswin (Governor of West Kalimantan from 1993 to 2003) and Yogie S. Memet (former governor of West Java from 1985 to 1993 and minister of the interior from 1993 to 1998), as well as several others are often mentioned in local conversations (Lumenta 2005:15).

In the early 1990s, two panglima perang and one local Iban member of the district assembly for the Golkar party went to Jakarta to gain support for the development of a border road. Using their military contacts, they managed to get an unofficial audience with General Mahmud Subarkah and eight other military persons in the Dharma Putera Hotel in Kebon Sirih, Jakarta. The general was a member of the People's Consultative Assembly (MPR) and one of Soeharto's advisers at the time. The Iban district assembly member claimed that he had known Mahmud Subarkah previously when the general was stationed in Putussibau. According to the Iban representatives, the General's reply to their inquiry about road development was to say, 'do not be disappointed, my brother, but there is no use for a road in the border area. It is too sparsely inhabited; there are more monkeys than people (banyak monyetnya daripada orang)'. The Iban answer was, 'So, General, how do we make people's living better than that of monkeys (Bagaimana manusia itu kehidupannya lebih bagus daripada monyet)?' Despite such harsh comments, the General supposedly promised to send more development funds to the border area. ${ }^{69}$

The Konfrontasi and subsequent anti-PARAKU operations thus became an important factor in deciding the later power relations along the border. Networks established during this period of militarization are important for an understanding of current loyalties and the roots of border

68 Colonel Soemadi is not to be confused with Brigadier General Soemadi mentioned earlier.

69 Personal interview, Lanjak, 23-3-2007. 
elite authority. As noted by Baud and Van Schendel in their theorizing on the historical dynamism of borderlands:

The role of the state [along borders] was...] determined by its relationship with regional elites. When borderland elites were well integrated into networks of state power, they could become important allies of the state in its effort to control borderland society. ... However, borderland elites retained an independent power base and were in a position to oppose state policies (1997:217-8).

As further noted by Sturgeon in her study of Akha village heads and their involvement in controlling local resources on the Burma, Thailand and China border,

With their role enhanced by state approval, small border chiefs [village heads] have reworked patronage practices, serving larger state interests while controlling local resource access and increasing their own wealth and influence (Sturgeon 2004:466).

Like the ethnic Akha elite, the Iban borderland elite have also claimed loyalty towards the unitary state of Indonesia while simultaneously engaging in and maintaining cross-border connections and loyalties. Sturgeon reports that 'by manoeuvring among multiple affiliations in more than one state, border chiefs have in fact constituted the border' (2005:32). But as mentioned by Peluso, in the Kalimantan context it would be misleading to: 'assume a level of elite machination and absolute power that has little historic basis among any Dayak subgroups' (2008:49). Although some local Iban figures attained certain favourable positions, these elite have never obtained absolute authority over local border communities and decisions taken; rather, their authority lies in their wide networks, high level of schooling and roles as intermediaries between the local level and the government bureaucracy.

The militarization of the borderland has continued until recently and there are still unfounded rumours circulating about Communists hiding deep in the forest. During the early days of my field research, I was told never to walk far away from the longhouse on my own, because there was a risk of stumbling into armed men, a reference to the PARAKU. It is difficult to pinpoint the exact year the PARAKU left the border 
area, as the records differ considerably. In October 1973 in the town of Simanggang one of the insurgent leaders, Bong Kee Chok, officially signed the so-called 'Deklarasi Sri Aman' (Sri Aman declaration), ${ }^{70}$ a memorandum of understanding and peace agreement with the Sarawak government. The PARAKU were subsequently given amnesty. But factions within the PARAKU saw this surrender as a mistake and restored their bases in West Kalimantan a few years later (Fujio 2005:502). Moreover, after withdrawing from Kalimantan in 1985 the insurgents continued their guerrilla warfare in Sarawak until another peace agreement in 1990 (Sarawak Tribune 1990).

Officially, the Indonesian government declared their anti-PARAKU efforts ended in the early 1970s by a total annihilation of the PARAKU rebels. However, according to Fujio Hara and locals interviewed in the borderland, the insurgents were present in the upper part of the border area until the mid-1980s. ${ }^{71}$ For example, Davidson and Kammen mention how in 1982 an ethnic Chinese man was arrested in the Lanjak area and accused of being involved with the PARAKU (2002:33). The 1982 incident fits well with local accounts of how an ethnic Chinese PARAKU rebel named Pecin in the early 1980s surrendered to a local panglima perang in Lanjak. ${ }^{72}$ Lumenta further notes that several PARAKU surrendered to the Iban in the upper part of the Embaloh River as late as 1986 (2005:20). Iban who worked for the military tell how the Indonesian army in 1982 gave orders to hang flyers or letters on rocks and trees in the forest telling the PARAKU to surrender. According to an Iban informant the PARAKU once did reply by leaving a letter on a rock along the Embaloh River. The letter supposedly revealed that the PARAKU still had more than 200 men in the area dispersed in 82 camps along the border. ${ }^{73}$

The episodes discussed here affected the Iban inhabitants in different ways. Certain historic parallels can be drawn between the times of raiding during the Dutch and the Brookes regimes and the period of armed confrontation along the border in the 1960s and 1970s. The pragmatic practice of betting on two horses at the same time in order to deal with

\footnotetext{
$7^{\circ}$ 'Sri Aman' is a Malay phrase for 'peace', and after signing of the memorandum the town of Simanggang was renamed 'Sri Aman' to commemorate the agreement. However, the Iban still use the former name of the town.

${ }^{11} \quad$ For similar claims see also Japari (1989:11-2). Japari was bupati of Kapuas Hulu from 1985 to 1995.$)$

72 Personal interview, Lanjak, 23-7-2007.

73 Personal interview, panglima perang, Embaloh Hulu, 12-6-2007.
} 
often conflicting outside demands is a strategy often applied among the ethnic communities in the borderland. In a region where state power and cross-border involvement fluctuate over time, this approach is understandable. In what follows, I will build on these legacies of the past by examining the subsequent period of resource control and struggle.

\section{NEW ORDER LEGACIES: AUTHORITARIAN RULE AND RESOURCE EXTRACTION}

When General Soeharto came to power in 1967, a key principle in his New Order regime ${ }^{74}$ was the idea of a strong unitary state: Negara Kesatuan Republik Indonesia, or NKRI. In this the military came to play a dominant role as the ultimate upholder of national unity. The military developed the 'dual function' (dwifungsi) doctrine that emphasized the role of the military as both guardian of state sovereignty and political, economic, and ideological overseer of the state. Under Soeharto, the military became entrenched in civil affairs, and they had a number of permanent seats in the parliament. Military officers also held top positions within all levels of government, district, and province, and played key roles in state-owned and private business corporations. For example since the mid-1960s nearly all governors and district heads in the province of West Kalimantan, have had some sort of military background. Promoting the 'national myth' of a unified state through the militarization of Indonesian politics was Soeharto's attempt, as commander in chief, to retain strong central control of the Indonesia nation. Instead of completely prohibiting political parties, the New Order government merged most parties into a single party known as Golkar (Partai Golongan Karya). The borderland of Kapuas Hulu has long been a Golkar stronghold, especially because of the large military presence. As numerous Iban informants describe the situation, 'if your community wanted any subsidies from the government or if you wanted your children to pass their exams, you had to vote Golkar'. Local Golkar supporters often accused other parties like the Democratic Party of Indonesia (PDI) of being a 'Communist' party made up of remnants of the banned PKI (Indonesian Communist Party) and PARAKU. Local elites were

74 Soeharto applied the term New Order (Orde Baru) to imply a transition in politics from former President Soekarno's Old Order rule (Orde Lama). 
generally strong supporters of Golkar and were actively engaged in party rallying during various elections.

As touched upon previously, the military presence in the borderland during the New Order era had a dual function: it defended the territorial borders of the nation, but it also defended national unity through its role as disseminators of the national ideology, Pancasila. As I will outline in the following paragraphs, military activities in the borderland were not only about defence and indoctrination, but also about economic gain.

\section{LARGE-SCALE TIMBER CONCESSIONS AND MILITARY RULE}

Until the late 1960s, little effort was put into harvesting the border area's extensive forest resources, partly due to the area's remote location and partly due to various political restraints. During the Dutch colonial period large-scale harvesting of timber in the remote parts of West Borneo was seen as unprofitable and not worth the investment needed. Consequently, little was done to control land and forest. As discussed earlier, the main issue at that time was the establishment of claims on the territorial border with Sarawak (Vandergeest and Peluso 2006:49-50).

In 1967, as a direct result of the anti-PARAKU campaign, the immediate border area was put under strict military control by the Indonesian state and categorized as a green 'safety belt' (sabuk pengaman). The establishment of the DOM (Daerah Operasi Militer) set the stage for major resource exploitation along the border. With the Basic Forestry Law No. 5 from May 1967, ${ }^{75}$ the central government could now assert authority over all state forest lands, without taking into account local people's claims to these lands. ${ }^{76}$ As part of his national development program, Soeharto consequently designated most of Kalimantan's forest as state forest (hutan negara). The government monopoly on all forests, and areas classified as such, created many problems for local populations, such as the loss of traditional rights to land and the use of natural resources.

In the province of West Kalimantan, President Soeharto divided widespread forest areas along the border into large timber concessions (Hak Pengusaha Hutan, HPH, or Commercial Forest Concession) that

75 Undang-undang Pokok-pokok kehutanan.

$7^{6}$ The Basic Agrarian Law of 1960 made this possible by formally categorizing all customary forest land (hutan adat) as state forest. 
provided the concession holder with the exploitation rights for a specific area for up to 20 years. ${ }^{77}$ Logging licences were in many instances awarded to military officers and border elites who had served along the border during the anti-PARAKU fighting in the 1960s and 1970s. In return for awarding the military this opportunity for economic gain, Soeharto received military support in upholding strict conformity to the New Order politics in the peripheral regions of the nation. Military involvement in the business sector was also a way to compensate for inadequate budgets and wages (Brown 1999; Human Rights Watch 2006). Since the 1960s, all the governors in the province of West Kalimantan have had a military background, as have many of the district heads.

In the West Kalimantan border region, Soeharto in 1967 (through the Ministry of Agriculture $)^{78}$ allocated huge tracts of forest $(843,500$ ha $)^{79}$ to a foundation created by the Indonesian armed forces named 'Yayasan Maju Kerja' (PT Yamaker Kalbar Jaya). ${ }^{80}$ In the 1960 s the military began, creating various foundations (yayasan) that handled their many business ventures such as logging. These foundations were exempted from paying taxes and benefited greatly from government monopolies on various sectors such as forestry. The Yamaker foundation was heavily linked to the Ministry of Defence and Security (Departemen Pertahanan dan Keamanan or Dephankam) (Human Rights Watch 2006; Jakarta Post 1999).

Despite being the principal permit holder, Yamaker possessed little forestry experience and did not have the knowledge and financial resources needed in order to carry out productive logging. Therefore, it often leased out its concessions to various timber contractors, both Indonesian and Malaysian. ${ }^{81}$ Interestingly, taking the anti-Chinese sentiments of the PARAKU time into consideration, the logging activities in the study area were often carried out in cooperation with ethnic Chinese entrepreneurs from the provincial capital Pontianak. These entrepreneurs possessed the technical expertise and economic investments

77 See Government Regulation 21/1970.

$7^{8}$ Decree of the Ministry of Agriculture, 1-11-1967 (HPH No. Kep/79/11/1967).

79 The Yamaker concessions were later extended in 1989 (SK Menhut No. 1355/Menhut-VI/89).

8o Yamaker was also given 224,000 ha of forest in neighbouring East Kalimantan, which combined with the concessions in West Kalimantan totalled more than one million hectares. For more information on Yamaker's activities in East Kalimantan, see Obidzinski et al. (2007).

${ }_{81}$ PT Yamaker coordinated, worked together with, or provided security to several logging companies operating in the area during this period such as PT Rimba Ramin, PT Benua Indah, PT Mekanik, PT Militer and PT Tawang Maju. 
necessary for such large-scale operations and allegedly cooperated with Malaysian Chinese companies in marketing the timber.

PT Yamaker combined economic exploitation with national security concerns, and its operations encompassed a stretch of border from Tanjung Datu, the most western tip of the province on the coast, to the upper part of the Leboyan River and Embaloh River in the east, approximately $400 \mathrm{~km}$ in length. ${ }^{82}$ The main activity of the foundation was logging to generate income for the armed forces, although in return for the HPH concessions, the company was officially required to improve the socioeconomic welfare of the border communities by promoting various rural development programmes.

In the late 1970 s, three Iban war veterans accompanied by prominent community leaders travelled to Jakarta to address the board of the Yamaker Foundation and lobby for their part of the border region to be opened up to logging. They argued that logging would bring prosperity to local communities, but it was the vast forest resources, and to a lesser degree the need to keep external threats (Communists) at bay, that quickly convinced PT Yamaker of the area's potential. In October 1980 the head of the Yamaker board (pengurus) in Jakarta, Major General R. Soebiantoro, issued a letter of declaration acknowledging Yamaker support of the request for local development made by these leading members of the border community. The letter stated that:

The community representatives have declared that the forest environment where they reside is still intact $(u t u h)$. This forest territory conforms (sesuai) to - Decree of the Minister of Agriculture No. Kep 79/11-1967 - and is part of the Yamaker forest concession $(\mathrm{HPH})$, and until this moment there has been no company activity (kegiatan) in this area. In accordance with the statement of the [Iban] representatives, the local community truly hopes that Yamaker will soon commence operating (dapat operasi) in their area, in order for the community to receive [economic] benefits (manfaatnya), and their safety from the PARAKU can be secured (dijaga). When the HPH is up and running, they [the representatives] request that some of the living requirements of the local people (penghidupan rakyat) be provided such as the construction of schools and community halls, and that the local community be provided jobs in the logging operations.

82 The entire length of this international border between Indonesia and Malaysia is circa $1200 \mathrm{~km}$ (BPS-KB 2006). 
Yamaker agrees that if it starts operating in the area this request will be granted (permohonannya akan dipenuhi) - Jakarta, 21 October 1980.83

Logging activities were initiated, and alongside the major role played by PT Yamaker, the Iban elite were granted licences to run their forest concession, PT. Lanjak Deras. It is here important to note that it was only a chosen few among the war veterans who received such great rewards for their help in fighting the PARAKU. Other veterans who actively took part on the side of the Indonesian military only received documents acknowledging their status as veterans and a promise of a pension that never materialized.

Consequently, these few Iban, empowered by military authority and their position as community leaders, opened up several communityforest territories for timber extraction on behalf of the wider Iban community. Not having the needed investment to start up logging themselves, they made financial support agreements with Malaysian Chinese and Iban from Sibu, Sarawak. A crucial instrument in attracting these external investors was the strong military backing. The concession was dubbed an 'Iban concession', although benefits ended up in the pockets of a few men (Harwell 2000b:94-5). As noted by Harwell, the granting of an 'Iban concession' is quite unique during the New Order period, as most other concessions was given to military officers and other powerful cronies of Soeharto. Harwell suggests that the granting of this local concession most likely was a reflection of the 'state's deep anxiety' about Communist infiltration in the borderland (2000a:95). The concession can therefore be understood as an attempt by the military to gain sympathy and loyalty among local leaders.

According to one informant, these negotiations were carried out without the knowledge (masyarakat kecil tidak tahu) of the larger non-elite community in the borderland.

The community did not know that certain leaders (wakil masyarakat) went to Jakarta and asked for the forest to be open for the welfare of the local community (kesejahteraan). Actually, it was not done for community welfare. They [the representatives] got duped (ditipu) by the entrepreneurs (pengusaha) in Jakarta and the leaders duped the community. The commu-

83 Surat Keterangan, Dewan Pengerus Yayasan Maju Kerja, No. 165/Kep/P.Y/X/1980. 
nity didn't know that the company was coming but could just stand and look with their eyes wide open (lihat dengan mata terbuka). ${ }^{84}$

This informant and several others claimed that one man who held the position of temenggong and panglima perang at the time (he has since passed away) had particularly strong ties to the ruling elite in Jakarta. He supposedly met with both Soekarno and Soeharto on several occations in his position as a panglima perang and veteran from the Konfrontasi and anti-PARAKU operations in the 1960 and 1970s.

During the subsequent period of resource extraction, little or no compensation was normally awarded to the majority of non-elite inhabitants for timber extracted from local forests. Yamaker did not fulfill its promises of developing the area and providing local jobs . For local communities the benefits were few, and even today, most people recall the logging operations of the 1980s and 1990s with indignation. As a local Iban farmer in the Lanjak area stated:

Only those [companies] who had HPH [forest concessions] permits (punyai ïin) benefited. The communities did not receive any benefits (untung) from forest cutting. They instead became traumatized (masyarakat diibaratkan traumalah)... We just received pocket money for buying sugar - we were sweet-talked (untuk gula saja) and eventually the revenue from logging was not spread equally (hasilnya tidak merata) generating social jealousy (cemburu sosial). Only the bold and the brave (berani) were favoured..$^{85}$

Traditional forest claims were largely disregarded, resulting in a certain degree of bitterness towards the timber companies and some of their partners within the border elite. Despite the initial promises of job creation implied in the company's name (Maju Kerja, or 'Advancing Employment'), the PT Yamaker workforce consisted largely of workers brought in from Java, and development efforts were generally half-hearted (Sinar Harapan 2005b). In spite of community bitterness towards PT Yamaker's broken promises, there were only a few occasions during the 1980s and 1990s when local communities showed their discontent with the timber companies through direct actions such as erecting roadblocks

84 Personal interview, Lanjak, 24-6-2007.

$8_{5}$ Personal interview, Lanjak, 24-6-2007. 
and claiming compensation. Their animosity mostly went unspoken in public, as timber companies enjoyed the protection of powerful military interests and were sanctioned by border elites and central state authorities. Wadley, for example, has noted how, during meetings between locals and company agents, the Iban elite (that is, temenggong and patih) directly discouraged the local communities from bringing grievances against companies (Wadley 1998:79).

With all forest land in the border region, as elsewhere in the province, now belonging exclusively to the centralized Department of Forestry, local communities had little legal ground for receiving compensation for trees cut on what they perceived as their traditional forestlands. Operating under broad state-supported authority over the forest granted to them, companies felt little commitment to reinvest resources in local development. In their dealings with local communities, company agents often talked about gaining permission from locals to carry out logging. However, locals were generally aware that the companies did not need permission from the communities, as they already had been granted permission by the central government. In order to prevent major local unrest that could end up affecting company business, most companies gave token assistance to communities affected by the logging activities. Most commonly, the companies helped build access roads to longhouses, gave rides on logging trucks, and supplied gasoline for generators and various other handouts. Compensations were also paid for damage to fruit and rubber trees during logging and the construction of logging roads. Formally the Indonesian Forestry Law obliged the companies to pay some compensation for destroyed property, and as most logging roads ran through locally claimed forest rubber and fruit tree orchards communities saw this as a possibility to benefit from the logging. Locals therefore attempted to claim ownership of felled trees and receive compensation (Wadley 1998). The local elite negotiated the amount of compensation. Besides representing the communities, the elite also received their own honoraria from the timber companies. Significantly, the temenggongs and panglima perang at the time were largely appointed by the government or military, and some were concession holders themselves.

Despite the split loyalty of local leaders and heavy military presence, some local communities maintained a certain degree of autonomy. For example, in the late 1980s when Yamaker began extending its logging operations in the Ulu Leboyan, the community of Rumah Manah began 
negotiating with the company. Besides compensation for destroyed forest gardens and graveyards, a special (written) contract was made stating, among other things, that Yamaker had to provide ironwood timber for a new longhouse. Despite several requests from the community headman, the company supervisors delayed fulfillment of their part of the agreement. Consequently, in the early 1990s armed members of the community confiscated all logging equipment from the main Yamaker timber camp located opposite the longhouse across the Leboyan River. ${ }^{86}$ After several failed attempts to negotiate with the company on site, a delegation of five community members travelled to Pontianak to visit the main Yamaker office to state their grievances. According to the community members, the manager of the Pontianak office, Mr. Akiang, refused to talk with the delegation, as he denied knowing anything about an agreement with the community. Not taking a 'no' for an answer, the delegation camped outside the company office for several days. They informed Mr. Akiang that the community of Rumah Manah would instantly stop all collaboration and make it difficult for the company to operate in the Ulu Leboyan. Not wishing to slow down its logging operations and to engage in potential violent confrontations with the community, the company agreed to provide the timber requested. Although little cash compensation was paid to the inhabitants of Rumah Manah, a logging road connecting the area with the main road to Lanjak was built, enabling motorized access to and from the area.

In the early 1990s, this road had passed the longhouse into the Ulu Leboyan and by 'accident' ran through an Iban cemetery where Bantin, the famous rebel, was buried. Having disturbed the dead, the company had to bring in the local temenggong from Lanjak to perform ritual expiation before the road construction could be continued. After this ritual involving the sacrifice of a goat and pig (at the expense of the company) was performed, the temenggong strongly advised the inhabitants of Rumah Manah to support the company and warned them not to engage in any more acts of vigilantism.

PT Yamaker concessions along the entire border were terminated in May 1999 by the Habibie government (1998-1999) because of gross mismanagement. Yamaker had already ended its logging operations in the Ulu Leboyan in 1994 due to lack of capital. The company was poorly

86 The same location was used as base camp for the Indonesian military during the anti-PARAKU fighting. 
managed and was not able to continue logging in the hilly area due to the heavy costs of building and maintaining roads and bridges on the steep slopes. The terminations of the Yamaker concessions were furthermore an attempt by the new government to make a political stand against Soeharto's former cronies. After disclosing that Yamaker was involved in large-scale timber smuggling across the border, ${ }^{87}$ Minister of Forestry and Plantations Muslimin Nasution issued a decree transferring logging rights along the Malaysian-Indonesian border from the military-controlled PT Yamaker to the government-owned company PT Perhutani. ${ }^{88}$ The minister announced that contracts were originally given to Yamaker because the forests along the border were considered a security zone, and it was thought prudent to have a military-linked timber firm manage the area. He further announced, 'Our decision shows that the government will not hesitate to revoke licenses or contracts of disobedient companies no matter who owns the companies' (Jakarta Post 1999).

Even today the Yamaker Foundation has apparently still failed to repay Rp3 billion (US\$309,000) received in Forest Resource Provision funds and Reforestation funds (Sinar Harapan 2005b). ${ }^{89}$ Like PT Yamaker, PT Perhutani also largely mismanaged its concessions and generated little local support. ${ }^{90}$ The company consequently suspended its logging operations in the area. ${ }^{91}$ By contrast, the Iban-headed concession PT Lanjak Deras was granted a ten-year contract extention after its leaders emphasized the concession's crucial role in the development of the area (Wadley 2006:117). PT Lanjak Deras was later in 1999 renamed PT Lanjak Deras Jaya Raya as it became a subsidiary of the company PT Benua Indah. The large Benua Indah possessed the needed capital to sustain logging in the area that PT Lanjak Deras lacked. ${ }^{92}$ Despite central government's revocation of Yamaker's logging rights, the military continued to impose its authority in the border area, but instead of

\footnotetext{
${ }_{7}$ Allegations of Yamaker engaging in illegal cross-border timber smuggling together with Malaysian Chinese had been made already in the mid-1980s (Tempo 1987).

88 Decree of the Ministry of Forestry and Plantations, 27-5-1999 (No. 376/Kpts-II/1999) and 16-82000 (No. 1007/Menhutbun-II/2000).

$8_{9} \quad$ Forest Resource Provision funds (Provisi Sumber Daya Hutan, PSDH) and Reforestation Funds (Dana Reboisasi, DR).

9o According to local statements, PT Perhutani was also engaged with the military, which provided security for the company.

${ }^{11}$ Decree of the Ministry of Forestry, 31-12-2002 (No. 10344/Kpts-II/2002) concerning the revocation of Decree No. 376/Kpts-II/1999.

$9^{2} \quad$ SK Menhutbun No. 844/Kpts-VI/99, 7-10-1999.
} 
doing so directly, the military allegedly indirectly cooperated with the Indonesian and Malaysian companies who entered the borderland after 1998. As noted by the Iban head of an environmental NGO working in the area:

The rights of Yamaker were withdrawn (dicabut hak), were taken away. Actually, the generals are still in the game (jenderal pun masih bermain). They are involved in all processes of those illegal activities; in fact, those were not illegal because they got permission of some generals who were involved themselves (beberapa jenderal juga yang terlibat dalam permainan ini). We just cannot prove it (tidak bisa membuktikannya). ${ }^{93}$

\section{MOULDING LOYAL CITIZENS AND ITS PARADOXICAL} OUTCOMES

As illustrated in the previous chapters, the creation of the territorial borderline dividing the island of Borneo in two has played a crucial role in moulding local Iban lives and strategies. In what follows, I will show that the contemporary dynamics cannot be fully understood without reference to the overall borderland experience and without taking into account these dynamic historic processes and long-term ethnic links. A meticulous investigation into different borderland practices as experienced by the inhabitants themselves is decisive in understanding the borderland milieu.

Here the historically conditioned affinity the Iban border populations have developed for neighbouring Sarawak plays a crucial role. Not only are the Iban a minority group within their own province, partitioned from a much larger population in a visibly more prosperous country across the border, but also successive colonial and national governments on both sides of the border have given them special treatment. This has allowed them considerable space to develop a strong sense of autonomy, heightening the sense of separateness that appears ubiquitous with border populations. Nevertheless, this sense of autonomy has also led to shifting and ambivalent relationships with various levels of government bureaucracy. After independence, the partitioned Iban population along

93 Personal interview, Pontianak, 2-3-2007. 
the border continued its arbitrary relationship with government rule, now with 'the state' taking the form of the new Indonesian Republic.

While the borderland was largely left alone as an autonomous entity in the first decade after independence, nationalist aspirations towards neighbouring Malaysia swiftly made the borderland into a combat zone of intense militarization and, decades later, major resource extraction and struggle. These initial Indonesian attempts to (violently) impose a sense of national consciousness among their border citizens resulted in paradoxical outcomes. The attempt to mould loyal citizens and to disseminate the message of nationalism was only partially successful. While a small segment of the borderland population vividly expressed their strong nationalist loyalty by voluntarily joining the fighting and in return gained some rewards, the nationalist indoctrination largely failed among the majority of the border population. This majority never came to develop a strong sense of belonging to a united Indonesian nation-state, primarily because of strong cross-border links, military violence and lack of immediate genuine rewards. Ironically, and despite government intentions to win its allegiance, the border population instead strengthened its orientation towards neighbouring Sarawak, Malaysia, both economically and socially. The long-term militarization of the borderland and a general exclusion from national development during the early stages of Indonesian state formation quickly destroyed any growing 'patriotic' feelings among the border communities and is today locally understood as a prime indicator of the Indonesian state's indifference towards its marginal citizens.

By confronting inherent assumptions of a strong and united state lying dormant within Indonesian national history, local counter-narratives often provide alternative histories. In this case borderland narratives provide meaningful insights into how national borders have been constructed in tandem with central state actors and border communities and not least how Cold War politics played out at the edges of the Southeast Asian states. Another important aspect of this early period in Indonesian state formation was the fact that the Konfrontasi and following counterinsurgency effort contributed in a major way to the consolidation of a strong and powerful Indonesian military elite. During these few decades of jungle warfare young military entrepreneurs proved their loyalty towards the nation and were later rewarded with key positions in the New Order regime.

As we shall see in the next chapter, the events unfolding in the bor- 
derland following the Asian economic crisis of 1997 and the fall of the authoritarian Soeharto regime in 1998 are perhaps not very surprising, especially given the critically important historical precedent discussed in the above chapters.

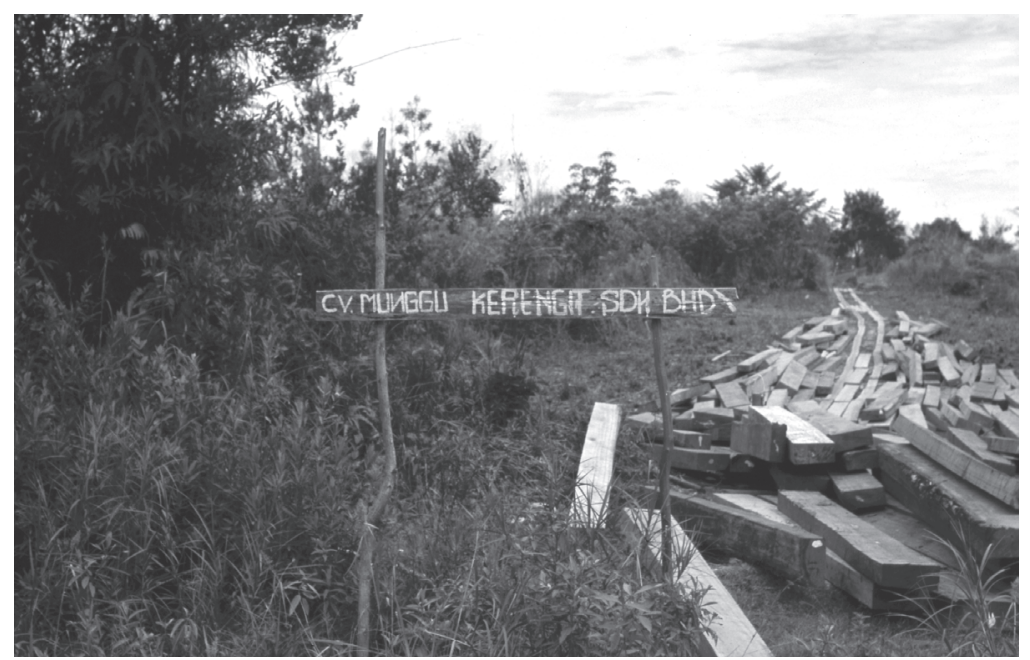

Fig 26: Hand painted sign on path leading to timbercutting site, 2000 (Photo courtesy Reed Lee Wadley) 


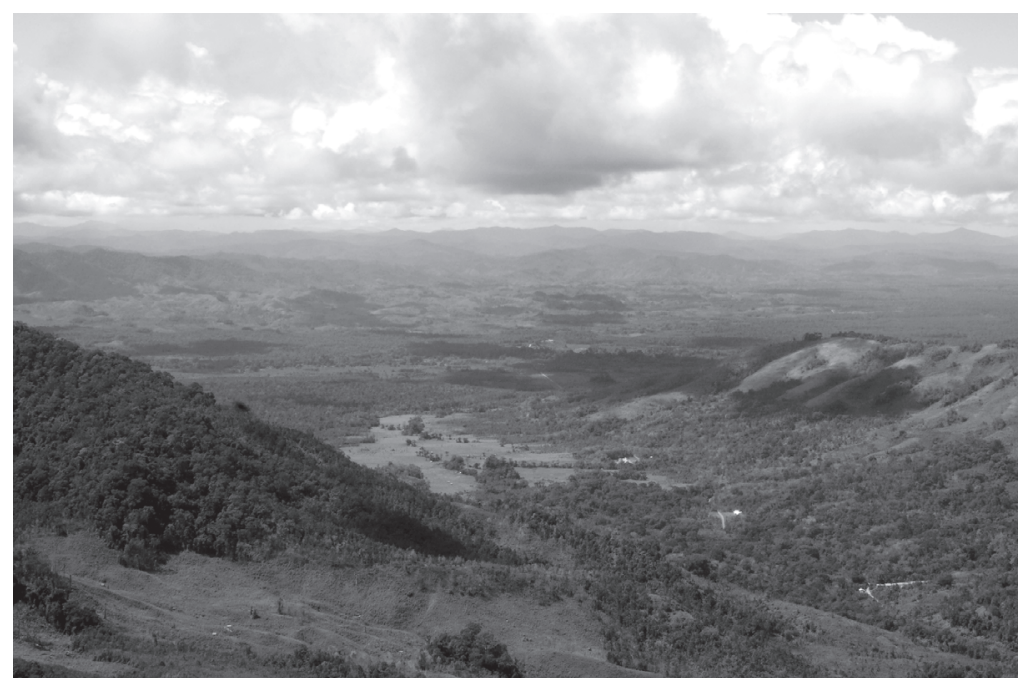

Fig 27: Mixed forest gardens, swiddenfields and logged forest along the border, 2007 (Photograph by author)

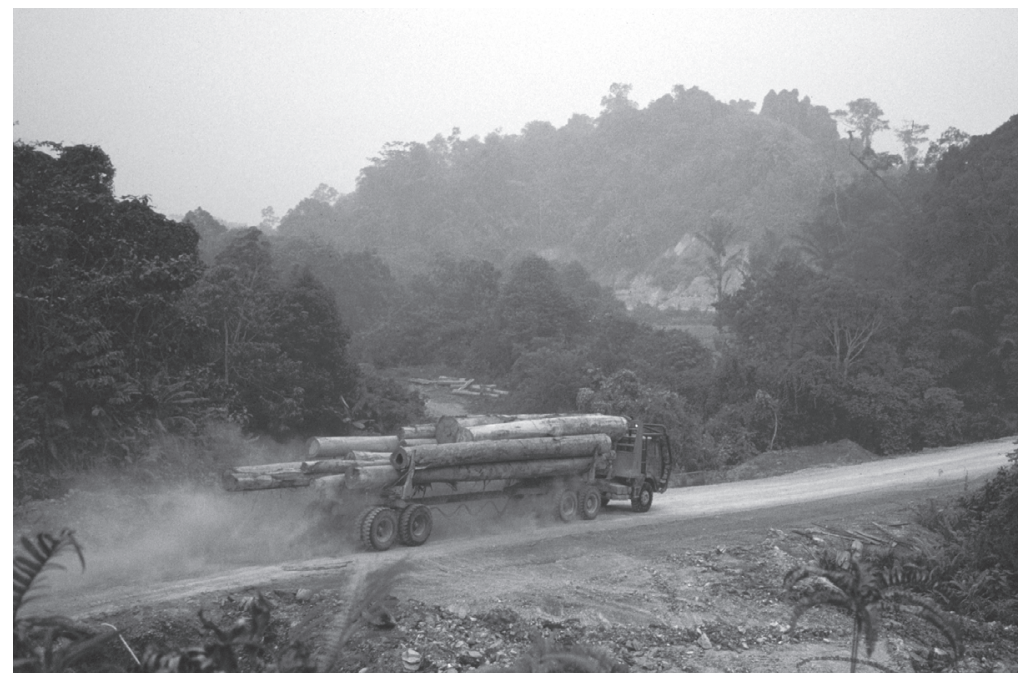

Fig 28: Logging truck transporting newly cut timber down to the border timber mills, 2003 (Photograph by author) 


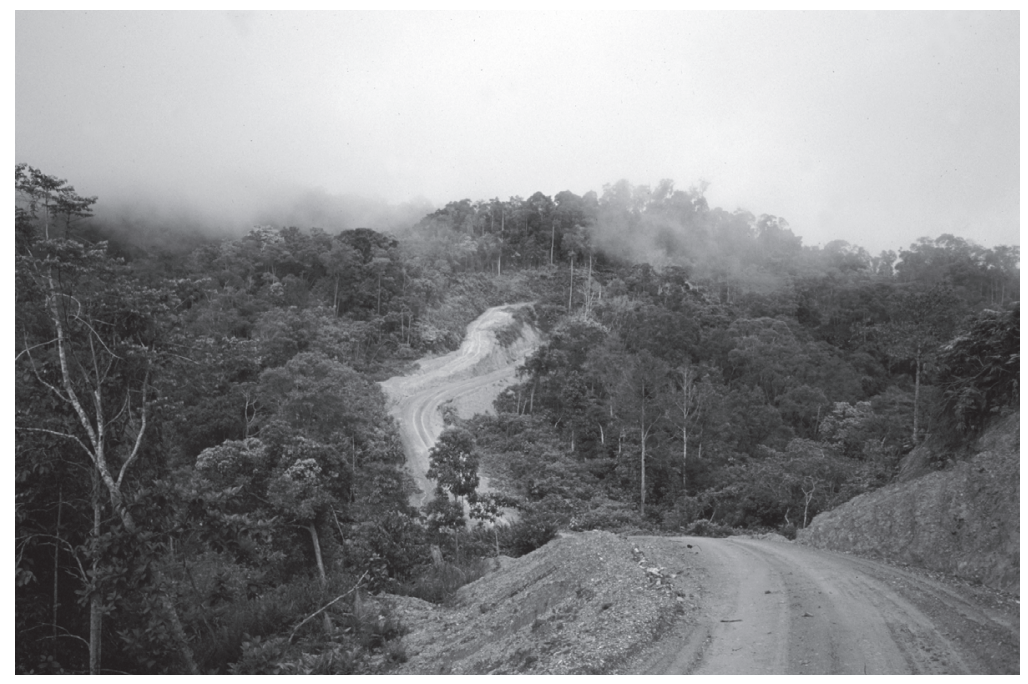

Fig 29: Logging road twisting through the low-lying hills along the border, 2003 (Photograph by author)

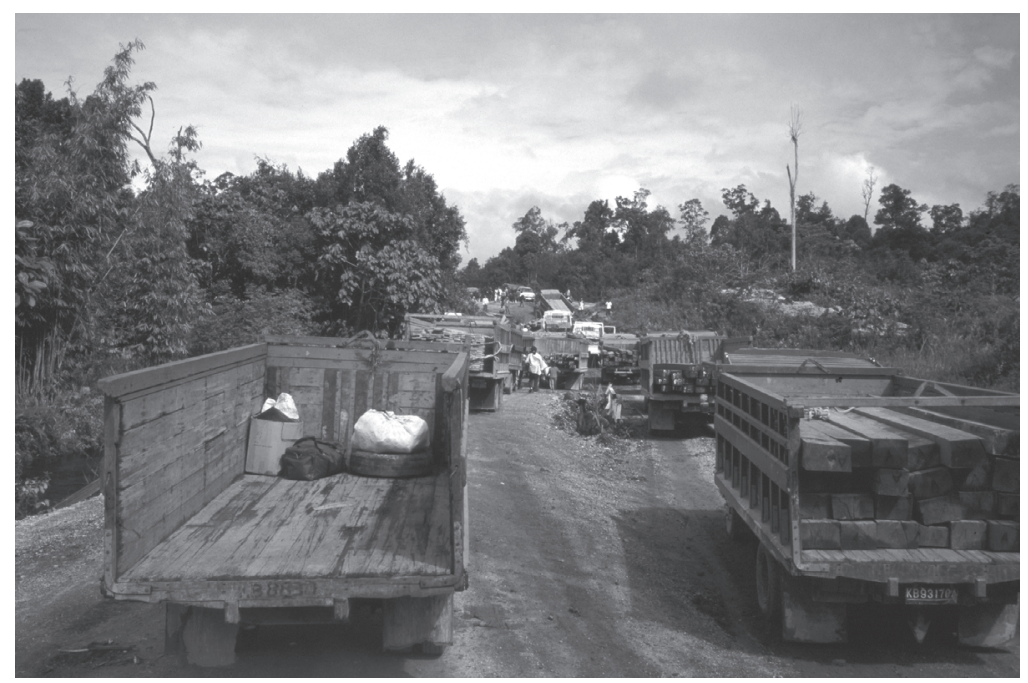

Fig 30: Trucks loaded with sawn timber moving towards the border, 2003 (Photograph by author) 


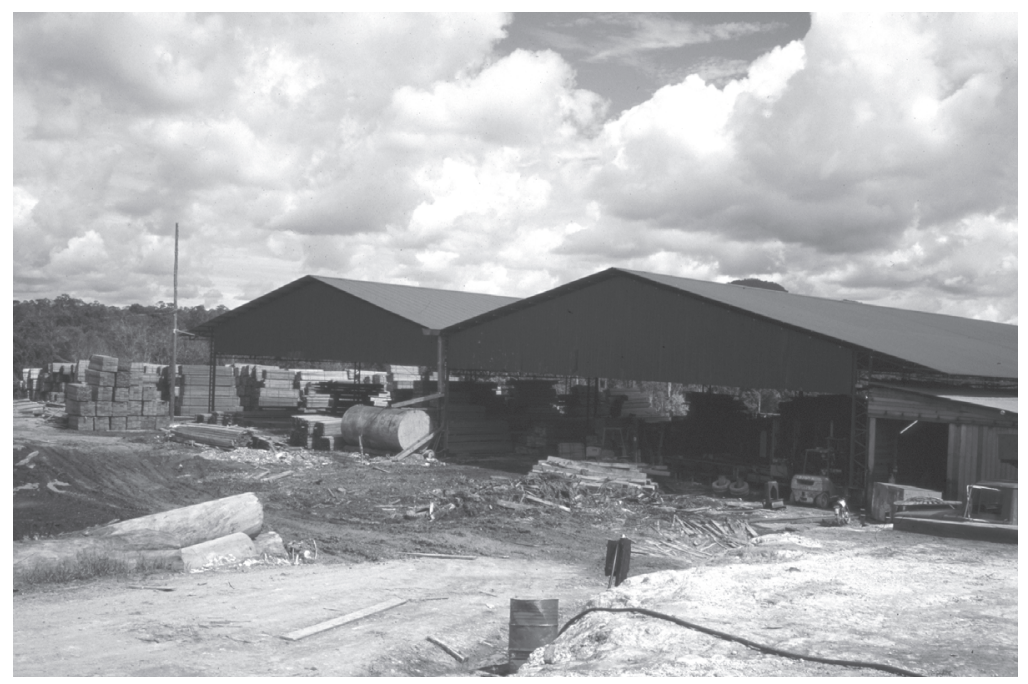

Fig 31: Aphengs large sawmill on the Indonesian side of the border, 2003 (Photograph by author)

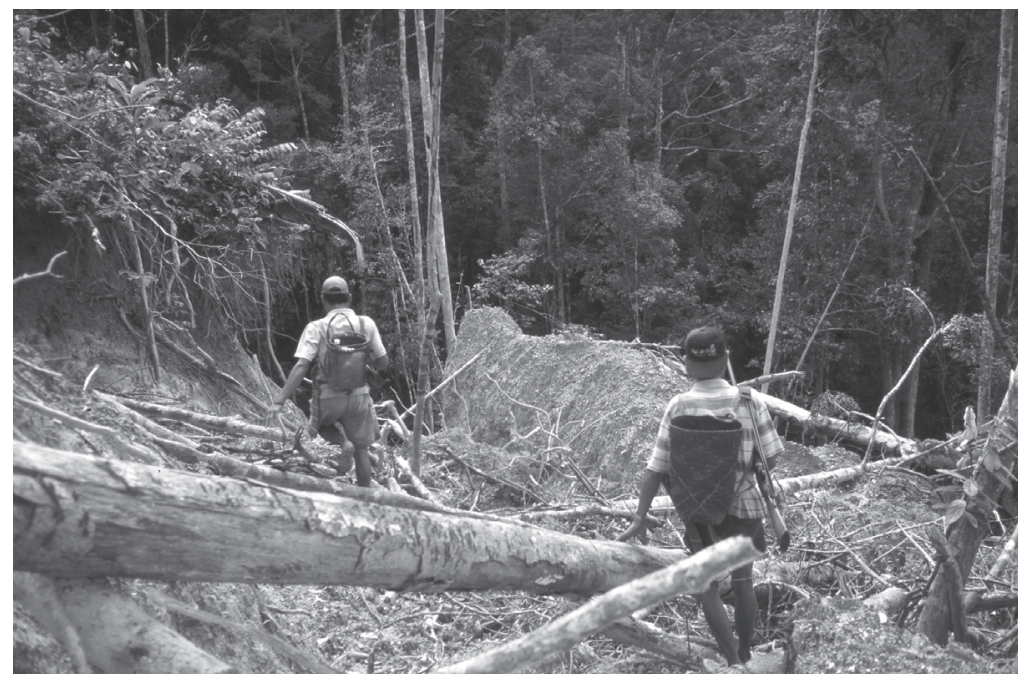

Fig 32: Newly logged forest and soil erosion, 2003 (Photograph by author) 